Historic, Archive Document

Do not assume content reflects current scientific knowledge, policies, or practices. 


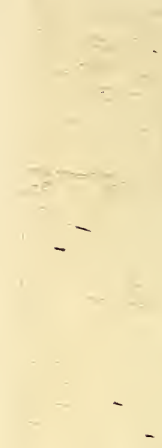




\section{PREMIUM OFFERS}

I have made arrangements with the publishers whereby I can offer a year's subscription to Fruitman and Gardener free with each order for plants amounting to $\$ 2.50$ or more.

The Fruitman and Gardener is a monthly journal devoted to the

interests of gardeners and fruit growers, and is practical in its

teachings and very instructive and valuable.

With an order amounting to $\$ 8.00$ or more I will include free a year's subscription to The Garden Magazine, published monthly by Doubleday, Page \& Company, of New York Ciíy.

As its name irdicates it is devoted to the interests of the garden,

and is a very high class magazine. The price was formerly $\$ 1.00$

per year, but has recently been advanced to $\$ 1.50$.

By agreement with the publishers I can offer one year's subscrip-

tion in connection with an order for stock from my list amount-

ing to $\$ 1.00$ or more, for the sum of $\$ 1.00$, thus saving you 50 cts.

With an order amounting to $\$ 5.00$ or more you may add 50 cents worth of stock, your choice.

Or with an order amounting to $\$ 10.00$ or more you may add 10 per cent. in stock as a premium, except on special prices given on strawberry plants in 5,000 lots.

Please notice that if you wish to take advantage of either of these premium offers you must so state when sending your order.

Also note that in either of these offers the amount shall be figured at catalogue price, and not where a "Special Price" has been quoted.

Also only one Premium with each order.

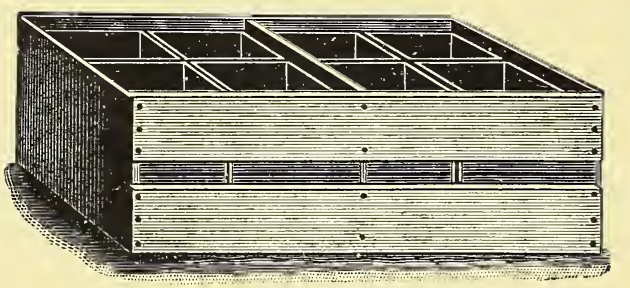

\section{Berry Crates}

\section{Berry Baskets}

\section{BEST GOODS---PRICES RIGHT}

Goods Sent in the Flat or Made $U_{p}$

Baskets [for Shipping Grapes and Peaches All Kinds of Fruit and Vegetable Packages

Catalog Mailed Free on Application. Address

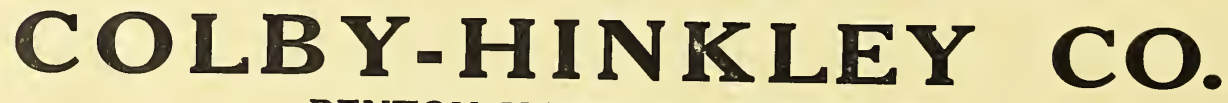

BENTON HARBOR, MICHIGAN 


\section{"Strawberry Plants That Grow."}

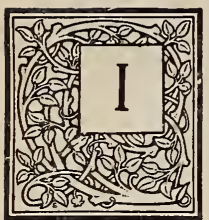

N AGAIN revising this our annual booklet "Strawberry Plants That Grow," I have endeavored to make some improvement in its appearance as well as in the contents trying to make it more helpful to my patrons and especially to those who are just commencing in the work of fruit growing either for pleasure or profit.

$I$ do not feel that an introduction is necessary to my old friends who have been receiving this booklet for so many years, but as I expect to reach many new homes this season a word of introduction will be in order: I have been in the business of growing strawberry and other small fruit plants for more than twenty years in our present location; selling through our catalogue and shipping to all parts of the United States and the adjoining Provinces.

Being situated in one of the greatest fruit sections of the country we are able to grow first-class stock more cheaply than can be done in less favored localities.

It is our aim to do business on Rooseveltian principles giving every one a "square deal." That we succeed generally is evi denced by the fact that many of our customers who bought of us twenty years ago are still our patrons.

These satisfied customers we consider our best recommendation and we shall endeavor to so conduct our business that we may merit a continuance of their confidence in the future.

I want to say a word in regard to conditions at shipping time last spring. We knew when writing our Cat-

alogue in the fall of 1908 that the crop of plants would be short in our own section, but we did not realize just how extended this shortage was.

However, we soon learned that it was very great and that the demand for stock was much heavier than we could supply.

Early in February I had to refuse orders for certain varieties and in March we had to return all orders that did not allow substitution, while by digging time we were practically

returning all orders that came as we were sold short on nearly everything at that time. Of course this did not please our customers and it certainly was not pleasant to us to have to return money.

However, it seemed better to give them a chance to purchase elsewhere if possible than to hold the orders as some of our growers did, until the close of the shipping season and then return the money with the order unfilled.

I could have sold all the stock that I had at prices nearly or quite double those we had made in the fall, but we did not raise the price of anything.

I am in hopes that this season we shall have plants enough to fill all our orders, as we have the best crop we have grown for several years; however, there seems to be a serious shortage in the southwest and we may see a repetition of last season's experience, and it will be as well for our friends to place their orders early. The order can be booked in January to be shipped at a later date.

We have said before, and wish to repeat it, do not condemn a variety from one season's experience, as another year may show it very differently, also different soil, or location sometimes changes a variety very materially. Then, too, the season of ripening will vary according to locality, some that we class as late may ripen earlier, or those described as extra early be nearer mid-season. We can only give general conditions and do not mean to misrepresent. I have never urged my friends to set largely of untried "Novelties," but rather to test the newer sorts upon their own soil in a small way at first. I do not list any that I am not satisfied have merit. Each year we drop some from our list; not always because we think them poor, but because we have enough $t h$ a $t$ are better a $n d$ that succeed over a larger territory.

We have had complaint in the past that some of o u r varieties of strawberry plants (notably, Warfield, Crescent, Senator Dunlap, and others of that type) were "small" and "worthless." O f course, this complaint was not from experienced strawberry growers, for all such realize that there is a great difference in the manner of growth of varieties. Those like Bubach, Clyde, etc., which make very few runners will make much larger plants than those of Warfield type, which set so many and make small plants. These small plants, if thrifty, will grow and make a full row and bear as large a crop in the "matted" row as the heavier growing plants. Generally the Warfield type has only one fruit stem to the plant, while Bubach and that type usually have several "crowns" and a greater number of fruit stems to each individual plant. For the grower who is able to give high culture, on a very strong, rich soil the latter class grown in hills or hedge row would perhaps prove most profitable. However, for the ordinary grower, the smaller type grown in half, or full matted rows, would prove as profitable, requiring much less work in their cultivation.

Our growing nursery stock has been inspected by the State Inspector of Nurseries and Orchards, and by him declared apparently free from dangerous insects or diseases. A copy of his certificate will be attached to each shipment.

From the prevalence of San Jose Scale many 
states have enacted laws requiring the fumigation with hydrocyanic acid gas of nursery stock shipped into their borders; to comply with these laws we have erected a fumigating house and are prepared to fumigate all stock shipped if so desired. Patrons living in states where this is required will please notify us when ordering. This law does not include strawberry plants, but raspberry and blackberry plants are included.

Our strawberry plants are all fresh dug at time of shipping, as we do not try to winter any in cellar.

I wish to emphasize this statement as in the past some have claimed that my plants have been held over winter in cellar. Let me say here that I never did this nor have I ever seen others that practiced such methods.

In propagating strawberry plants for sale we always set from one year old beds which have not fruited. We also set the different varieties in blocks of several rows each, thereby obviating the danger of mixture, liable where different sorts are set in alternate rows. In digging, we usually take up the entire row, discarding the original plants and such of the tip plants, not well rooted, therefore we have no exhausted stock to send out.

In digging strawberry plants our help work in the field when the weather is fit, lifting the plants with "potato hooks" when taking the plants from the soil, stripping off the surplus leaves and runners and tying in neat bunches of twenty-five (we always aim to put in twenty-six). After tying, the bunch is carefully heeled in until the required number of that variety is dug, thus the roots are not exposed to the air for any great length of time.

When the weather is unfit for the work to be comfortably done in the field, the plants are picked up in baskets and carried to the packing house or other shelter where they are stripped and bunched as before described. But after the plants have been handled in this way the roots never straighten out so nicely as when bunched at once upon being taken from the soil; hence I think the plan of stripping and tying in the field preferable, notwithstanding others claim to the contrary.

Experienced strawberry growers know that a slightly wilted plant is much surer to grow than one that has been kept too moist and packed with too wet moss or other packing material. There is nothing that will cause strawberry plants to heat in shipping quicker than to have them too wet when packed.

By this I do not mean to infer that we purposely wilt our plants or aim to pack them too dry, for we mean to havel our moss just right; I don't want our customers to feel that the plants are permanently injured if slightly wilted.

Of course sometimes our packages get broken in transit through careless handling and if found in such condition upon delivery our patrons should refuse to accept and pay charges upon the same, notifying me at once; then we stand a chance of collecting damage from the transportation company, but if once accepted it is hard to collect damage. Also if plants have been delayed and have been an unreasonable length of time on the road, do not accept them, as they are quite liable to be injured, especially strawberry plants.

In other seasons we have claimed and wish again to repeat it, that both our soil and climate seem especially adapted to the growth of strawberries. We also claim that we grow and can furnish just as good plants as any other grower, the claims of wonderful superiority of some others notwithstanding.

It will be a great help to me if my friends will speak a good word for my plants, if they have the opportunity, and it will be thoroughly appreciated.

If more than one catalog is received, please hand to some one whom you think will be interested in small fruits.
C. E. Whitten,

Bridgman, Mich

Dear Sir:-The last 425 plants came to hand in good shape and are all set and I must say that the first order for 6,800 plants together with these last ones were the choicest lot of plants I ever set and I set these nearly all myself and had to pack some of the first order away in cellar for a week and nearly every first order away in cellar for a week and nearly every
plant is growing. Have only seen two or three dead

I ordered 400 plants from Kansas and the first lot was set before yours came and only about 150 will grow. I complained of the plants and they refilled order and the express on this was 45 cents and the plants were not worth setting. I gave them away to a neighbor if he would set out what he thought would grow. I thank you for fair treatment and generous grow. I thank you for fair treatment an
count and assure you of my future orders. Yours truly,

\section{F. B. LESOURD.}

\section{E. Whitten}

Laurel, Mont., May 8, 09.

Bridgman, Mich.

Dear Sir:-The plants were received in good condition; am well pleased with them.

Yours respectfully,

W. L. ALLARD.

Alto, Mich., May 13, '09.

C. E. Whitten,

Bridgman, Mich

Dear Sir:-I received your card and plants April 29 and set them May 3. They arrived in good condition and are all doing finely, scarcely a plant of the whole two thousand failed to grow. Thank you for your generous count and prompt dealing.

Very respectfully
C. E. Whitten

Bridgman, Mich

January $9, \cdot 09$.

Dear Sir:-Enclosed find my order for strawberry plants. Having received plants from you for years back, I know where to get plants that are true to name and never mixed; always young plants well rooted, well packed and over count. Hoping I can get the Pocomoke as they are one of the best strawberries going.

Your's respectfully, JOHN P. WYLIE.

C. E. Whitten Bridgman, Mich.

Morley, Mich., May 10, '09.

Dear Sir:-Plants received in due time. The day I received them it commenced to snow; snowed four days. Practically it has stormed ever since. Have unpacked, set some out, the balance have heeled out until weather settles. Will say they are in the best condition. Every plant alive and growing nicely. condition. Every plant alive and
never saw nicer goods from any place.

I sincerely thank you for such fine stock. Will try and do you good here. If you put out another book for next year please send me one. Yours,

\section{J. S. ABDELL.}

C. E. Whitten Bridgman, Mich

St. Paul, Minn., May 18, '09.

Dear Sir:-Received the 2,000 Senator Dunlap yesterday and was very much pleased to get them as was so short of them. The Brandywine plants that I got from you from you are growing fine. missing in the 3,500 . The raspbertes are doing well, also. If $\mathrm{I}$ need any plants next year I will know where to get them and if any of my neighbors need any plants I will recommend you as a man who gives a square deal. Again thanking you, I am,

Bradley Street. R. 4 .

\section{EUGENE MARIEN.}




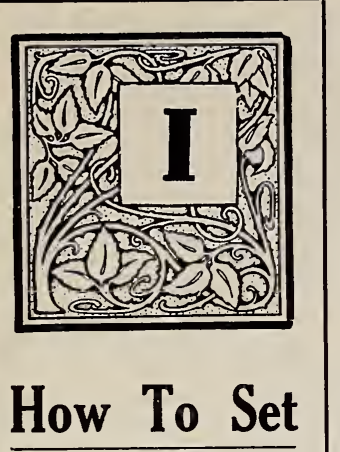

\section{and Grow}

\section{Strawberries}

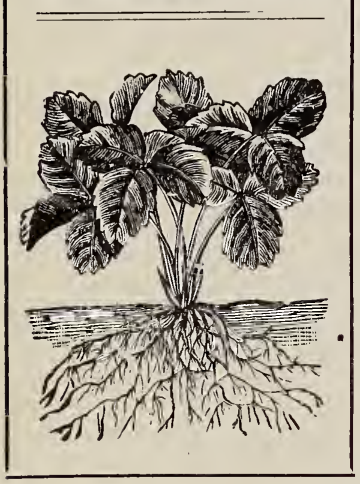

HAVE HAD numerous applications for instruction alo $\mathrm{ng}$ this line, and while I have endeavored to give a partial description of my method of culture, I can hardly give any general $\mathrm{rules}$ that should apply to all localities.

THE SOII AND IOCATION best adapted to strawberry culture will vary somewhat in different sections. In a general way we have said that any soil that would grow good crops of corn or potatoes would grow good strawberries, and while this seems to be a pretty safe rule, it is also true that in order to grow them to the best advantage it is necessary $\mathrm{t} o \mathrm{~h} \mathrm{a} v \mathrm{e}$ soil especially adapted. One of the first requisites of the ripening $\mathrm{fru}$ it is moisture, and care should be taken that $\mathrm{th}$ is is provided. Hence a very dry or loose, sa n dy soil would not be a safe location, although in moist seasons a fair crop might be harvested. Neither is a stiff clay adapted to strawberry growth, as very early in season it cannot be worked without becoming cloddy, and later is apt to bake, and the plants will suffer more than on sandy soil. It would seem that a sandy loam or loam with slight mixture of clay shouud if properly handled give the best results.

DRAINAGE-Having chosen a soil retentive of moisture, it next becomes necessary to prepare for proper drainage in case of excessive rainfall, unless the natural lay of the land is such that no water will stand upon the surface. Tile drains are the only practical ones to use. Open ditches will, perhaps, answer this purpose, but are unsatisfactory in many ways. They occupy too much land and are in the way of cultivation, while tile drains are much more convenient and fully as effective. In sandy soil I would advise using tile not smaller than four inches in diameter, and larger for mains, according to length and amount of water to carry. I have laid a good many three-inch tile and have had to take them up and replace with larger on account of their filling with sand. Of course this was where we had only moderate fall.

My idea is to hold the moisture in the soil at a depth of about two feet. Tnen in case of drouth we can by frequent cultivation bring moisture near the surface where most needed.

FROST-In planning your strawberry field care should be taken to avoid frosty locations, such as very low land near marshes or lakes, also valley where there is no chance for circulation of air, as these localities are very liable to heavy frosts, when higher land or that more open to circulation would show very little, if any. A hard frost at blossoming time often ruins the en- tire crop, hence the desirability of choosing a situation as much exempt as possible.

MANURING-Where the soil is at all deficient in fertility, I would advise using well-rotted stable manure. If this can be applied to the soil the year previous and some cultivated or hoed crop grown, then the following season the land must be in the best possible condition for setting strawberries.

Some writers advocate the plowing under of a clover sod in preparation for this crop, but I am always doubtful of this method on account of the white grub, the larvae of the May beetle, which is quite apt to infest such soil. Perhaps if only recent seedings were so treated, this pest would not trouble, but I would warn all against plowing up an old sod to set strawberries, as the grubs would be almost sure to destroy the greater portion of the plants set. Never plow under green or very coarse and strawey stable manure just before setting strawberry plants, as it would cause the soir to dry out very quickly and will also burn the roots killing the plants wherever it comes in contact with them. This is important and should be avoided if possible.

Any good commercial fertilizer may be used; one rich in nitrogen rather than potash to be preferred. This should be sown broadcast on the land after plowing and well harrowed into the soil.

FITTING THE SOIL-Having selected your site with reference to proper drainage and fertility of the soil, begin by plowing as late in the fall as possible before the ground freezes. This late plowing is beneficial in that the soil lays up loose and open, that frost may act upon it more readily, also leaving it in a condition to absorb more moisture in the spring, which may be drawn upon later in the season in case of drouth. It also tends to kill a great many insects which live over winter in the soil, some of which are quite troublesome and injurious to strawberry growth. The white grub is undoubtedly the worst of these, but as they seldom if ever lay their eggs in freshly cultivated soil, if my previous suggestions regarding the preparation of the site have been followed there will be no danger.

I like to plow quite deep where there is good depth of soil, eight inches at least, unless this brings the subsoil to the surface, which should not be done under any circumstances. As soon in the spring as the season has fairly opened, just as early as the soil will work up mellow, we harrow the land with a springtooth harrow (any other implement that will do the work thoroughly will do as well). There is not much likelihood of doing this part of the work too thoroughly, as it is much easier to properly fit the land before setting the plants than afterward. We generally harrow with the furrows first then diagonally each way. I would then immediately follow with a heavy roller, or if you have no roller at hand, a plank drag. (or "float," as we call it) heavily weighted will do as well. This firming of the soil is important as it is almost impossible to se plants properly if the soil is not reasonably level and firm at the surface.

MARKING OUT-This may be done in any manner that will give a very shallow straight mark to set by. A light sled marker that will make three or four marks at once is very handy and could be made by almost any one. The spacing of the rows will depend upon the method of growing chosen for your field.

IF FOR HIII CUITURE, which consists of growing the single plants, cutting off all rnnners as fast as made, which causes the plants to "stool out" or grow additional "crowns" which will each produce fruit stems, the rows should be from two and one-half to three feet apart and sixteen to eighteen inches in the rows. If to be cultivated 
both ways or in check row then two or two and one-half feet would be about right.

I would recommend this method to all those who wish to grow fancy berries and are willing to give the extra culture needed. This system requires a rich or fertile soil; it certainly would not pay on poor soil. Then, too, only certain varieties seem adapted to this treatment. Sorts like Bubach, Dornan and others of this class, while those like Warfield, Michel, Crescent or Excelsior and other heavy runners, would prove disappointing.

THE HEDGE ROW is quite similar to hill culture. The rows should be from two and one-half to three feet and twenty to thirty inches in the row; the freer runners the greater distance. The first runners are turned into the row and held in place with soil until they have struck root, generally about every six or eight inches in nearly a straight row, later all extra runners are kept cut off. There are different implements which are manufactured for this purpose, but I think a good sharp hoe in the hands of an active workman will be fully as satisfactory as the machines. Plants grown by either of these methods are claimed to remain healthy and fruitful for several seasons.

THE HATF MATTTD ROW should be set about three and one-half feet apart and eighteen to twenty-four inches in the row. The runner's are all kept off until about the middle of summer. then allowed to root until row is about one foot wide, after this all runners should be cut oft. This should give a fine show for fruit.

THE IMATTED ROW is the system adopted by the greatest majority of fruit growers, although without doubt other methods would prove more profitable. The rows are set four to four and onehalf feet apart and plants from twenty to thirty inches in the row. The runners are all allowed to root, running the cultivator always in the same direction and narrowing it up as required. At times, if the season happens to be favorable to plant growth, and the soil is rich, almost the entire surface will be covered with plants. This method might be allowed on poor soil where fewer plants would be grown or with varieties that make few plants ordinarily, but if Michel, Warfield or other heavy runners are allowed to grow in this manner they will prove very disappointing from the fact that there will be many blank or barren plants. Varieties of this type would do better in half matted rows.

SETTING OUT-As to the manner of setting the plants there are so many theories advanced which differ from mine that I feel rather backward about giving my method. But as it is very simple and requires no special implement to work with, using instead a common spade for opening the holes, and not requiring any very complicated movements in placing the plants in the soil, I will give what I consider the easiest as well as the best method. I am well aware that some good authorities condemn the use of the spade for this purpose, but it is and has been used in this community-which is one of the greatest strawberry sections of the state-for the last thirty years or more, and I do not think any one can show a more evenly perfect stand than we have in this region. I can show blocks of a number of acres with scarcely a plant missing.

The first operation is the opening of the holes, which is done just ahead of the setting, not leaving them to dry out. In doing this the operator proceeds along the row, thrusting the spade in the center of the mark already laid out, spacing equal distances according to methods chosen, quite close if to be grown in hills, and farther if for matted row.

This should be nearly the depth of the spade and if the soil is properly prepared this will not require much effort, but if the soil should be very solid it will require some pressure of the foot to sink it to the proper depth.

The spade should be given a slight motion to right and then to left; when withdrawn if the conditions are right you will $\mathrm{f}_{\text {save a }} \mathrm{V}$-shaped opening which will readily receive the roots of the plant. Care should be taken not to weave the spade back and forth too much, as this tends to open too wide a space at the bottom of the hole, making it hard to close properly and leaving a chance for air space, causing plants to dry out and die.

The greatest pains should be taken in getting the plants into the soil, and here is where you should place your most careful workmen; or better still do this part yourself, if possible. Have the plants set in a shallow basket or other receptacle, with the roots moistened-if the roots are very long they should be cut back about three inches. The plant should be held by the upper part of the crown and placed in the spade opening at about the same depth it grew, which should bring the crown even with the surface; now let the operator press the soil firmly against the plant with a good, strong pressure of the foot, first on one side and then on the other, being careful to see that the opening is entirely closed that air may not enter and dry out the roots.

CUITIVATION-As soon after setting as practicable the surface soil should be stirred very shallow, being careful not to disturb the roots of the plants, also not to cover up the crowns or heart of the plant, the latter will cause the plants to die, especially in damp weather, by rotting or smothering the crown. This early cultivation is essential for several reasons: First, to be sure that all the openings near the plant are filled, also to preserve moisture if the weather is dry by arresting evaporation through capillary attraction. This shallow cultivation should be kept up through the season, never allowing the surface to crust. There are a great many makes of cultivators which will do this work all right. Generally we use a one-horse steel frame with twelve or fourteen straight teeth. This simply pulverizes the surface, and one can work very close to the plants, but it is necessary to do some hand work with hoe in order to loosen all the surface and keep down weeds. The latter is very important, as one cannot successfully grow two crops on the ground at the same time.

Perhaps I should qualify this claim for shallow cultivation a bit by saying to treat the soil in this way only in dry seasons or on very light and dry soil, as if the season is wet or the soil low and heavy it becomes necessary to stir the soil deeper in order that it may dry out somewhat.

The blossoms should be pinched out of all spring-set plants, as it is not advisable to let them ripen fruit the first season, as it weakens the growth of the plants and is liable to kill them outright.

All runners should be cut off until the first of July, when if matted row is wanted, the runners may be allowed to root until the desired row is obtained, after which all runners should be kept trimmed off.

MUICFING OR WINTER COVERING-AS soon as growth ceases in the fall, and before ground freezes hard, the surface of field should be well covered with some sort of mulching, either long straw, wild hay, corn stalks, or other litter, If free from foul weed seed, will answer the purpose. We have grown several acres of sowed corn on purpose for this covering and find that it works quite well. We sowed quite early, about the middle of May, broadcasting about one and one-half bushels per acre and allowing the crop to stand until thoroughly ripened before mowing with machine, leaving on the ground as it fell un- 
til just about time to use as covering when it was taken up with a horse rake and hauled onto the strawberry field. We find that this material "stays put" better than the wild hay, as we have had very high winds the past fall and have had to replace the hay, and in some parts of the field this second handling was worse than the first on account of its having been rolled and twisted into all manner of shapes. For this reason I would advise spreading hay or straw when slightly damp if possible and placing a little soil upon the top at short intervals, which will help to keep it in place in case of high wind.

Some advise using coarse stable manure as a covering and if free from grass seed this might be advisable as it would both fertilize and protect the vines from frost. However, I generally "fight shy" of stable manure on plants that I wish to fruit the second season or for longer period, as I have sometimes seen a good stand of clover and timothy on what was supposed to have been a strawberry field.

As soon as growth commences in the spring this covering should be taken nearly or entirely off the plants, but may be left between the rows as a mulch to preserve moisture, also to keep the fruit clean at picking time.

RENEWING AN OID BED-We seldom try to keep a strawberry field longer than the second season, however, it usually pays to pick a second crop although some think it better policy to set a new field each spring and plow down the old one after fruiting, thinking that with this system the land is not so apt to be run or become seeded to noxious weeds. Many plow under the old beds after fruiting and sow some quick growing crop to plow under again, such as cowpeas, or other legume, where season is apt to be hot; buckwheat or rye for more northern latitudes. We have tried sowing corn in order to grow a crop for covering material, but this does not return anything to the soil and should not be practiced unless manure is applied at time of sowing.

Many different methods of renewing an old bed are suggested nowadays and I feel rather diffident about giving instruction along this line. However, if the matted row system has been followed and the field kept mulched, it will be necessary to get rid of the covering material first and there is no better way than by burning if season is dry enough to do this quickly. If field is at all weedy it should be mowed, then loosen mulch and if very heavy over plants remove partially to space between the rows; when thoroughly dry, and a brisk wind is blowing (just before a shower if possible) set your fires on the windward side and let burn over quickly as possible.

If properly done you will have a clean field and you may think your plants are all killed. Instead you will have killed many injurious insects and fungi. It will be necessary to commence cultivation at once and if the matted row is too wide we take a furrow away from each side of the rows making a "back furrow" or ridge in the middles. While the rows are in this shape we go over them with a hoe cutting out a part of the old plants and whatever weeds may have gained a foothold. If the weather should be hot and dry it will be necessary to hasten this part of the work and to commence working down the ridges at once. We find that an ordinary "double shovel" or corn plow does best for first time through then following with either one or two horse cultivator until the middles are thoroughly worked out and soil carried up to the row again. If an inch of fresh soil is covered over the crowns it will be no detriment, but rather a benefit in urging a new root system to start above the old. Cultivation should be continued through the growing season as needed.

With a season of reasonable moisture this manner of treating a field will surprise the uninitiated with the remarkable growth made, and by fall it should look as well as the year previous. The only chance for failure would be a protracted drouth at the time of firing, or burning over without wind, when the heat would be apt to injure the crowns of plants and perhaps kill them entirely. If hill or hedge row were used the plow would not be needed, but commence with cultivator immediately after firing.

\section{Number of Plants Required to Set One Acre.}

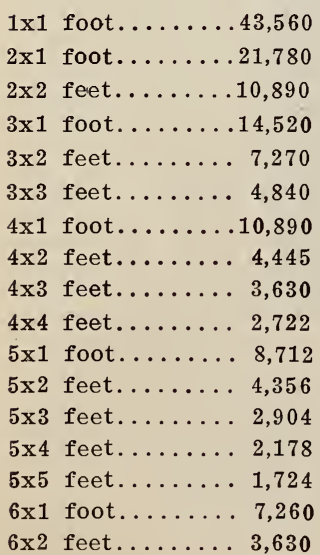

$6 \times 3$ feet.......2,420

$6 \mathrm{x} 4$ feet. . . . . 1,815

$6 \mathrm{x} 6$ feet.......1,210

$7 \times 1$ foot......6,222

$7 \mathrm{x} 2$ feet.......3,111

$7 \times 3$ feet......2,074

$7 \times 4$ feet....... 1,555

$7 \times 5$ feet....... 1,244

$7 \times 6$ feet...... 1,037

$7 \times 7$ feet...... 888

$8 \times 3$ feet....... 1,815

$8 \times 4$ feet.......1,361

$8 \times 5$ feet...... 1,089

$8 \times 6$ feet...... 905

$8 \times 7$ feet....... 77 ?

$8 \times 8$ feet...... 680
$6 \times 5$ feet.......1,452

\section{Table of Express Rates from Bridgman, Mich., to points named below.}

Albany, N. Y....\$2.15 Alton, Ill. ...... 1.40 Anna, I11. ........ 1.60 Annapolis, Md. ... 1.75 Beloit, Wis, ..... 1.75 Bloomington, Iil. . .85 Borden, Ind. .... 1.40 Cedar Rapids, Ia. . 1.50 Centralia, Ill. .... 1.65 Charlevoix, Mich. 1.25 Cleveland, O. .... 1.40 Clinton, Ia. ..... 1.20 Columbus, $\mathrm{Ky} \ldots .22 .50$ Columbus, O.... 1.50 Creston, Ia...... 2.15 Davenport, Ia... 1.20 Decatur, Ill...... 1.20 Des Moines, Ia... 1.75 Detroit, Mich..... 1.00 Evansville, Ind... 1.80 Farina, Ill........ 1.40 Gn'd Rapids, Mich. .60 Harrisburg, Pa... 1.75
Humboldt, Tenn..\$2.40

Indianapolis, Ind.. $\mathbf{1 . 0 0}$

Jackson, Mich... .80

Jackson, Miss..... 3.50 Jefferson City, Mo. 1.90 Kalamazoo, Mich. . .50 Lansing, Mich.... 1.00 Lexington, Ky.... 1.80 Little Rock, Ark... 3.40 Louisville, Ky.... 1.20 Milwaukee, Wis... . .80 New Albany, Ind.. 1.20 N. Y. City, N. Y... 1.90 Pittsburg, Pa..... 1.75 Rochester, N. Y... 1.25 Sandusky, O..... 1.25 Sharon, Tenn.... 2.75 Shelbyville, Ind... 1.40 Sioux City, Ia..... 1.40 Sparta, Wis...... 1.50 St. Louis, Mo.... 1.50 Still Pond, Md.... 2.50 Wheeling, W. Va.. 1.50 


\section{STRAWBERRIES}

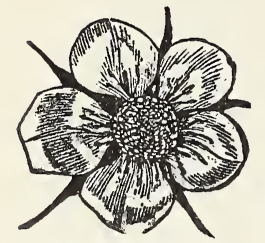

PERFECT

BLOSSOM.

All strawberry blossoms are either staminate-also called perfect-or pistillate, generally called imperfect.

The imperfect varieties which are all marked (Imp.) in catalog, should have a perfect variety, marked (Per.) set every third or fourth row to properly pollenize the blossoms of the imperfect sorts.

There seems to be a mistaken idea with some that this mixing of varieties is necessary with the perfect as well as the imperfect sorts; but this is not so. The perfect sorts are self pollenizing and will bear as well if set by themselves.

When the imperfect sorts are properly pollenized they are considered by some as more prolific. However, this may be there surely is no reason for any prejudice against them.

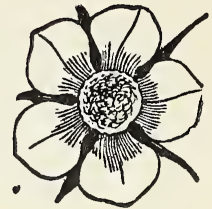

IMPERFECT BLOSSOM

Success depends in a great measure upon getting healthy stock, true to name. This is the kind we always aim to send out.

If by mail, add 10 cents per 25,25 cents per 100 for postage. At thousand rates, by express or freight.

\section{SOME NEW VARIETIES.}

CFESAPEAKE-(Per.)-I shall head the list over two acres the past season and the berries with this comparatively new variety which I re- were mostly all shipped to Boston, with the exceived from the introducer, W. F. Allen, of Mary- ception of a few sample crates to New York. In land, and whose e v e y instance description is as follows:

"This variety is as late as the Gandy and more productive; furthermore, it will thrive and bear an elegant crop on s o i 1 entirely too light to produce good Gandy berries. It is equal to the Gandy in size, superior to it in firmness and shipping qualities, and in eating qualities the Gandy is no comparison. I $\mathrm{n}$ flavor it $\mathrm{r}$ a $\mathrm{nks}$ with William Belt, Brunette and others of that class. Therefore, i $\mathrm{n} \mathrm{t} \mathrm{h} e$ Chesapeake we have attained to a greater d e g r e e than in any other variety three of the strongest points that go to make up a valuable commercial berrythese are firmness, quality and lateness. When these g o o d points a $\mathrm{re}$

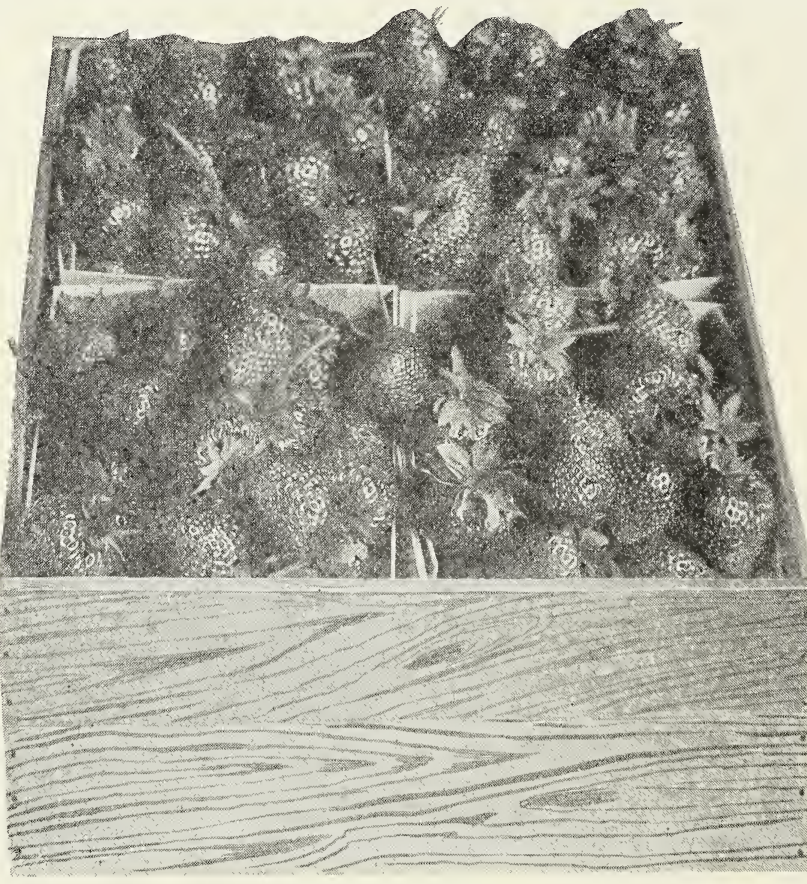

CHESAPEAKE. e v e ry instance
they brought the top market price, selling one week straight at seventeen cents, which was from two to three cents more than the best Gand y berries we re bringing a $t$ the same time. Everyone who saw it, both growers and dealers in $\mathrm{th}$ e fruit, w e r e very enthusiastic. The plant is a strong, upright grow er with thick, leathery and very dark $\mathrm{g} r$ e $\mathrm{n}$ foliage; leaves are almost round and entirely free from rust. The stems or fruit stalks are upright a $\mathrm{n} d$ unusually strong, holding almost $t \mathrm{he}$ entire crop from the ground. This variety, in addition to its other good qualities, is unusually easy to pick, and therefore very attractive to pickers."

aded to the fact that it is of uniformly large size, very attractive in appearance and being one of the most healthy and vigorous growers, puts it nearer perfection than has yet been reached by any other berry, and I can conscientiously say that if it succeeds in other sections as it does here it is the best strawberry in the world today. I fruited

I fruited a small block the past season and was so well pleased with its behavior that I am very sorry that I did not set more in order that I might have a larger stock to offer my friends and also have a goodly amount left for fruiting.

It certainly was as handsome as any strawberry I ever saw growing; the foliage was wonderfully 
strong being the largest I ever saw on any variety without exception, very tough and leathery, and of the most brilliant green, while the berries were of almost perfect shape being bluntly conical; its color is rather light red but ripens evenly and is red all over, it also is a very firm berry making an ideal shipping sort.

I tried to get photographs of this variety but was not very successful. I show one which represents the top of a crate as packed for shipment, not especially assorted, but taken as they run on the row. This gives a fair representation of size and shape.

Another point in favor of this variety was the fact that absolutely every berry came to maturity, no buttons, or nubbins, the last berries being of perfect form and fair size.

We picked these as late as any variety, except perhaps the Blaine, which is the latest we have.

I have only a limited stock of this variety as the plants grow very large and not many on the ground. I would advise all my friends to test this for themselves and am confident they will be pleased. $25,25 \mathrm{c} ; 100,75 \mathrm{c} ; 1,000, \$ 5.00$.

BLAINE-(Per.)-I secured this from the originator in lowa last spring and have not fruited it except on young plants; these produced fine, large, glossy fruit of fine quality. The plants have made a fine growth, not excelled by any, and they are large, very tall, with perfectly healthy foliage. I advise my customers to give it a trial.

The originator says: "It is a cross of the Bederwood and Lovett. It is a perfect blossom berry, has large, stalky plants, very healthy f o $\mathrm{l}$ i a $\mathrm{g}$ e light green colo $r$ a $n$ d broad leaves. Makes plenty of runners for a good crop. The ber$\mathrm{ry}$ is very large, firm and of the best color and flavor. It is the best shipper I have ever raised and I have lested over 100 variet i e s. Ripens just after the Aroma. When the Aroma is gone I begin on the Blaine. I have the Aroma downed on three points-size, flavor and shipping qualities.'

The above was the description of this variety given in my last

year's catalog. I fruited this in a small way the past season and find the originator's claims very nearly fulfilled.

It is a very late variety, the latest of any with us last season, and promises to be very productive. The appearance of the berry would suggest Gandy parentage although Mr. Blaine claims otherwise.

For a late market sort I think this will be a winner, and would recommend it as such.

Twenty-five, $20 \mathrm{c}$; hundred, $60 \mathrm{c}$; thousand, $\$ 4.00$

FIGHIAND-(Imp.)-Introduced for the first time last season the Highland comes before the public with stronger endorsements than most new introductions. For four years it has been fairly tested on the grounds of the Ohio Experiment Station and found the most prolific of any variety tested. The following is quoted from the Ohio Station Bulletins: "Highland was the most pro- lific variety in our collection. It is very promising and desirable, especially for the grower who is situated near a good home market. Fruit medium to large, bluntly conical; color bright scarlet; flesh red clear through. Plants very large, strong and vigorous. Flowers imperfect and quite resistant to cold. Highland gives bright promise of being a great business berry and a money maker for even the small planter."

Above is description as given in last year's catalog.

I fruited a short section of row the past sea. son where they had been left in our propagating beds without proper pollenation and was very much pleased with the show of fruit especially late in the season as the berries of this variety seemed to hold on the vines after ripening several days without spoiling.

I set quite heavily of this sort last spring and have made a good growth. I will offer it this season at following prices:

Twenty-five, 25c; hundred, $75 \mathrm{c}$; thousand, $\$ 6.00$.

FENDAII STRAWBERRY-I set out only a few hundred plants of this variety last spring and as I have never seen it in fruit I can only give the originator's description which is as follows

"This splendid berry originated in our garden at 
In length of season it is certainly remarkable. In 1907 we picked berries from it on the 25 th of May and the last on the 10 th of J'uly. With the same care and under like conditions, it produced twice as many berries as the Senator Dunlap, Corsican, Glen Mary, William Belt, Marshall, and three times as many as the Gandy. In 1906 it yielded at the rate of sixteen thousand eight hundred quarts per acre. It throws out a great many runners, which root splendidly in a very short time; in fact, the roots of this variety excel anything we have ever seen in the strawberry line."

I have a limited amount of plants to offer this season and will price as follows:

Twenty-five, $35 \mathrm{c}$; hundred, $\$ 1.00$.

THE HFRITAGE-(Per.)-This is a new seedling strawberry, originated by Mr. J. E. Heritage, Marlton, N. J., and this is his description of it: "The plant is very large, of extremely heavy texture, some single crown plants carrying foliage with a spread of 20 or 22 inches. Deep rooted and extremely free in fruiting, beginning to ripen its fruit about early mid-season and continuing to very late. Another prominent feature is that the fruit stems continue to shoot so late that during the early picking season there are many blossoms, which feature indicates to the experienced grower their long season of productiveness. The berry is dark, shiny crimson to the center. Has a perfect blossom. Carries an unusually heavy green calyx (adding decidedly to its market value). Extremely large from the first picking to much above the average for the main crop, and continues large after the better known varieties are gone."

I set a block of this variety last spring, getting my stock from the East, and while I have not seen it in fruit, only as the spring set plants were allowed to set a few stems of berries I am thoroughly well pleased with its manner of growth and general appearance. I would candidly urge all to give this new sort a careful test feeling quite sure that it will become a standard sort when better known.

I have a fair stock of this variety and will price low.

Twenty-five, 25c; hundred, 75c; thousand, $\$ 5.00$.

DICKrY-(Per.)-This was one of the novelties of 1907 , originated by J. D. Gowing of eastern Massachusetts, and introduced by C. S. Pratt, who sent out the Sample ten years ago. We quote Mr. Pratt's description:

"It is a better berry than Sample; it is as large and productive, and is very firm; colors all over -no green tips; very fancy. The Dickey will produce as many quarts of fruit as the Sample, and will sell for three or four cents more per quart in the market. I have been growing straw. berries for forty vears, and have never seen a finer thing in the berry line in my life. The Dickey is a long-season berry. Last year, (1906) it commenced to ripen at the middle of June, and on July 18th Mr. Gowing picked five crates of fine fruit."

I have never seen this in fruit, however, the plants make a good vigorous growth and promise well for productiveness. I have only a few plants to spare this season, as I shall set largely of it for another season's trade.

Above description is taken from last year's catalog and $I$ cannot add much to it at this time as our plants of this variety were all dug for shipping before I was aware of it leaving nothing for fruiting as I had fully intended there should have been. I have a good fair stand of plants to offer this season.

Twenty-five, 20c; hundred, 60c; thousand, $\$ 4.00$.

PRIDF OF MICFIGAI-(Per.)-This is a new variety found growing wild in this vicinity by one of our neighbors, Mr. Peter Weinheimer, and grown by him for several years before being offered for sale.

It was finally offered to the public through Mr. Baldwin of this place, who describes it as the best strawberry grown today; claiming that it will outyild any other variety. The berry is of good size and good color, being a dark red to center. It is a very firm berry making a good shipping variety, and is also a perfect flowered sort making a good pollenizer for pistillate sorts. A very thrifty and strong upright growing plant, setting plenty of runners. It is second early in season of ripening. Do not confound this with the Kellogg strain Pride of Michigan which is an entirely different sort being a pistillate variety.

I have never offered this before as I generally go slow with new sorts, but after watching this for several seasons I am satisfied that it has merit and will furnish a limited amount from stock which I received direct from Mr. Weinheimer.

Twenty-five, 25c; hundred, $75 \mathrm{c}$; thousand, $\$ 5.00$.

NORWOOD-(Per.)-This is a new variety introduced the season of 1908 by L. J. Farmer, of New York. I will give the originator's description as given in Mr. Farmer's catalog:

"The Norwood strawberry was named and given the first prize by the Massachusetts Horticultural Society at the exhibition of 1906 . This strawberry is supposed to be a cross between the Marshall and Corsican, as it came up where the Marshall had been grown and near where Corsican was grown at the same time.

The Norwood is believed to be the best allaround strawberry in existence. The plant is strong and healthy, making a liberal number of strong runners, but not excessive, The berry is conic and regular in shape; not a cockscombed berry was found this season. The quality is unsurpassed, and the size unequalled, some attaining the enormous size of three inches in diameter. Four such strawberries would fill a box and be crowded. Color, bright red all the way through, growing darker with age, is firm, a good keeper and will ship well. Has a perfect blossom and holds its size well through the season and remains in bearing a long time. Picked the first box June 18 th, and the last one July 18th. The largest berries were found in matted rows or beds although the plants had received no extra culture.

Dozen, $\$ 1.00$; twenty-five, $\$ 1.50$; hundred, $\$ 5.00$.

\section{Hanging Rock, O., May 5, ’09.}

\section{E. Whitten,}

\section{Bridgman, Mich.}

Dear Sir:-My strawberry plants arrived in first class condition, and were the finest plants that I have ever bought. They were the finest, in that they were the nicest size and that they were the most uniform in size. I had my ground thoroughly prepared when the plants arrived, and have succeeded in getting them planted with the ground in fine moist condition. I set them in an extra rich piece of soil and am going to grow them by the hill system. I set them sixteen inches upart in the row, with the rows two and one-half feet apart.

Out of the 1,700 plants that you sent me, I don't believe there were more than a dozen plants that I had to discard.

Your substitution of Pocomoke for Dornan was entirely satisfactory, for I know what Pocomoke is, although I have always been anxious to try Dornan.

With best wishes for your success and thanking you for fair dealing, I am,

Yours respectfully, ROY KELLOGG. 


\section{EXTRA EARLY SORTS}

Under this head I am offering three varieties that I think are the best of their season; altho perhaps not as rich in quality as some of the later sorts still their extreme earliness of ripening will make them an acceptable addition to any collection.

IUTHER-(Per.)-Or, August Luther, as some prefer to call it, was originated by Mr. A. Luther, of Missouri, and grown by him several seasons before it was offered for sale. The Ohio Experiment Station was first to call attention to it, giving the following report in 1897: "From A. Luther, perfect, un-named seedling, plants vigorous and prolific, berries medium to large, conical, usually with long slender point, light scarlet, flesh light red of good quality, valuable for its earliness. Is far more prolific than Michel's Early and far larger. Earlier, larger and more prolific than Rio. It is regarded as the best early rariety tested at the United States Agricultural Station."

I shall still place this variety at the head of the list of extra earlies, as I have found nothing yet that I consider better. It has a very pleasing appearance, being of a very bright red color and almost always of perfect shape, a slender rather sharp pointed berry. It ripens evenly, no "green tips," and will ripen its full crop in a very short space of time, this feature making it a good market

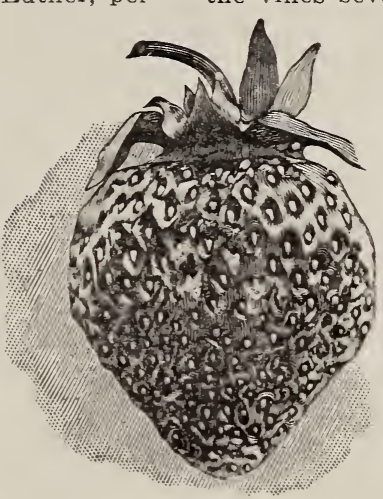

LUTHER
RID BIRD-(Imp.)-This is the new variety that I received from W. F. Allen, of Maryland, and which unfortunately was listed by him as perfect when in fact it was an imperfect variety.

Through this blunder my test row was without an early pollenizer, the only perfect flowering sort near being Chesapeake, a very late variety. Consequently the first bloom failed to pollenize and the berries were mostly "buttons;" later however, the row made a very good appearance and the berries seemed quite firm and stood on the vines several days after ripening without injury, showing good shipping qualities. I was very favorably impressed with this variety and think if set with either Luther or Excelsior it will prove a decided acquisition to our extra early sorts.

As I have had so little experience with it I will give Mr. Allen's description as given in his catalog:

"This is a valuable new early berry which first attracted my attention in Mississippi. It was highly recommended to me, and I was induced to set a few plants, and was satisfied from the first that they made a very rank growth of as healthy and vigorous plants as I ever saw. I paid no special at tention to it until it came in fruit the past season. It ripened with the Excelsior. By this I do not mean a day or two later, but I mean eually sort. It is also a very thrifty grower making a full row of medium sized plants. Last year we were not able to fill our orders for this variety, but this season we have a good stock of well rooted plants and I shall recommend it to all wanting a very early berry.

Twenty-five, $15 \mathrm{c}$; hundred, $50 \mathrm{c}$; thousand, $\$ 3.00$

EXCrISIOR-(Per.)-An extra early berry. Has given us a good erop of berries. Berry is dark red, of good size, one of the best shippers. It is a good plant maker. Plant healthy, blossom perfect. It is claimed to be a seedling of the TVilson crossed with Hoffman. Originated in Arkansas.

Some growers claim this as the best early market variety, and where dark colored, tart berries are wanted, this sort will surely please.

In direct contrast to the Luther this variety is a long-season variety and while it ripens its first berries at about the same season as Luther it continues much longer in bearing.

Twenty-five, $15 \mathrm{c}$; hundred, $50 \mathrm{c}$; thousand, $\$ 3.00$. as early. It is twice as productive and when I say this I mean it will bear two quarts where the Excelsior will bear one. It is highly colored, not quite so dark as the Excelsior, and makes a better showing. The berries average larger and hold up better. I consider it away head of that good old standard market sort.

"The berry is very tart, and would not be considered very good eating without plenty of sugar, but as a first early shipping berry, so far as I know of, it has no equal.. This is not a long description, but it gives you the facts as I have seen it, and as the berries have done for me."

We have a good stock of these for the coming season and the plants are strong and stocky, showing a tendency to stool or throw out extra crowns or fruit stalks this feature being exceptional for the extra earlies, as generally this class are not very heavy croppers, usually sending out only one fruit stalk.

I would recommend a trial of this variety by all looking for an extra early market berry.

Twenty-five, $20 \mathrm{c}$; hundred, $60 \mathrm{c}$; thousand, $\$ 3.50$.
C. E. Whitten,

Ridgeway, O., April 27, '09.

Bridgman, Mich.

Dear Sir:-The thousand strawberry plants and grape vines arrived promptly and in good order. Same have been set out and $99 \%$ of strawberries are growing.

A customer of ours asks me to order for him 300 strawberry plants. Please ship this number of Senator Dunlap by U. S. express.

Yours respectfully,

$$
\text { O. D. BRUNGARD. }
$$

C. E. Whitten,

Hannibal, Mo., April 6, '09.

Bridgman, Mich.

Plants arrived in good condition. Good plants. Thanks.

J. S. SMITH.
C. E. Whitten,

Van Wert, O., April 23, '09.

Bridgman, Mich.

Dear Sir:-I wish to acknowledge the receipt of plants. They came through all O. $K$. and just what I ordered. I opened bunches and heeled them in the ground, waiting for a little more setled weather to set them. Remember me with your catalog next spring.

\section{Truly yours,}

R. No. 9 ,

GEO. A. WELCH.

Upper Troy, N. Y., May 30, '09.

C. E. Whitten,

Dear Sir:-Plants came Friday in good condition. Am well pleased.

G. A. LOMAN. 


\section{SECOND EARLY VARIETIES.}

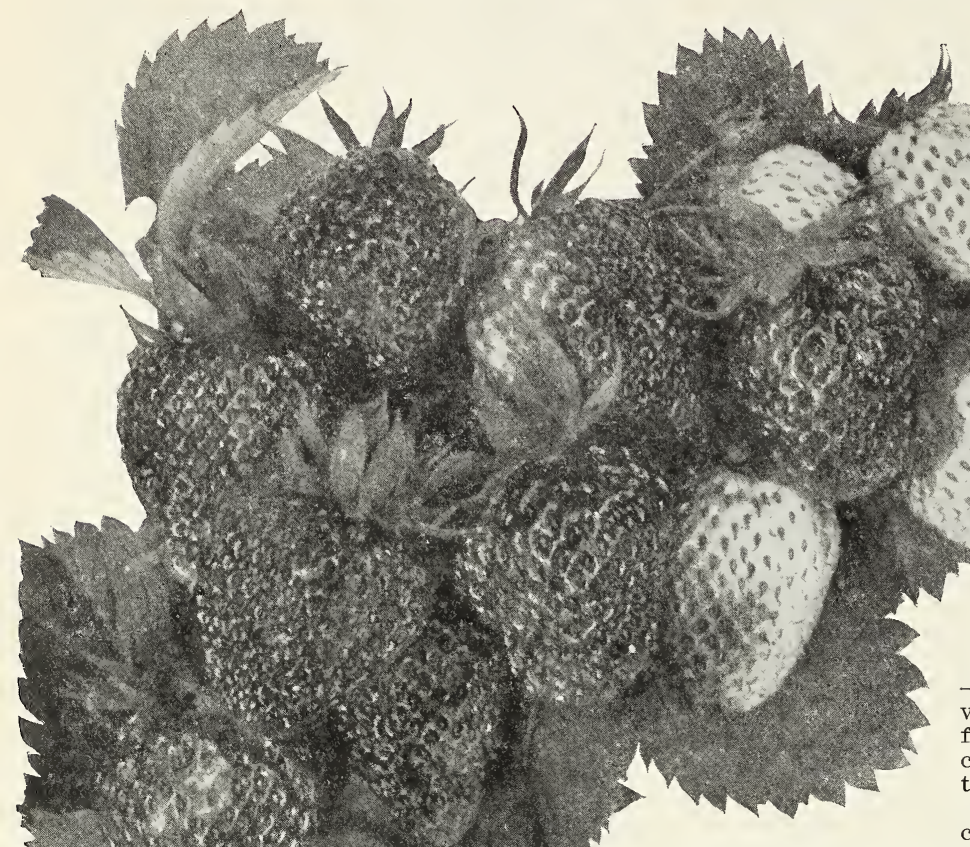
enearance. It is a runner, which becomes a fault on moist, rich soil unless the plants are kept thinned out. The introducer says: "We have the greatest confidence in this variety and believe that it will in the near future take its place among the more prominent standard kinds. The plant is almost perfect in its, way. We have several times called attention to its toughness and ability to endure hardships. It is small, slim, very deep-rooted, and as great a runner as the Warfield. With us it has always proven very productive. The fruit is generally large, never of the largest size, however; is conical in form, regular, never misshapen, bright or slightly dark red, very glossy, firm, a splendid keeper and shipper, most excellent in quality, and one of the best canning berries we have ever known. Its season is second early and it bears a long time."

The above was my first description of this sort and the lapse of time has proven the predictions true, as Senator Dunlap has become the most popular of any variety of strawberry grown; not only in this section, but nearly all fruit growers who have tested it say the same, and a great many say that if they were to be limited to one variety, it should be the Senator Dunlap. In fact many large growers are setting their entire acreage to this sort. All plant growers agree in saying that they sell more of this variety each year than of any other.

I have always recommended Senator Dunlap, for either market or home use, and I wish I were able to describe its merits more fully; however, no one can make a mis-

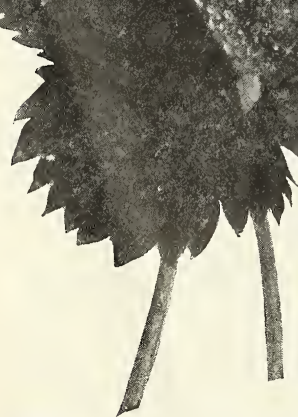

SENATOR DUNLAP. second early sorts, or doing equally well planted alone.

take in testing it as it is

While the season of ripening is given as second early, it in reality could be classed as a mid-season variety as it has a very long fruiting season.

Twenty-five, $15 \mathrm{c}$; hundred, $50 \mathrm{c}$; thousand, $\$ 2.50$.

WARIIEID-(Imp.)-This variety is still very popular as a market sort, although the Senator Dunlap has practically usurped its position at the head of the list, which it held before the advent of that very popular sort. The two together make a good team and are quite similar in appearance when in the crate. However, Warfield is a sourer berry and a little deeper red in color thus making it one of the very best for canning; it also holds its color in the can which is a very important point in its favor. In plant growth this variety is quite similar to Senator Dunlap, except it does not root so deep on light sandy or gravelly soils and is more liable to 
suffer from druoth. While the individual plants are quite small and usually have only one fruit stem, it is remarkable the number of quarts produced by a lightly matted row on good strong soil.

Twenty-five, $15 \mathrm{c}$; hundred, 50c; thousand, $\$ 2.50$.

SPIENDID - (Per.)- Originated at Sterling, Illinois. Plant a vigorous grower, equal to Warfield in this respect. Blossoms perfect. Berries are borne on tall fruit stalks and are large, firm, and of fine color. Ripens evenly all over, globu. lar, very productive. Few, if any blanks. No mistake can be made in using this variety to pollenize Warfield, Crescent and other pistillates. Early to mid-season.

TVe have a good block of these for coming season and $I$ would recommend it as a first class variety for market where quantity is more of an object than quality. $25,15 \mathrm{c} ; 100,50 \mathrm{c} ; 1,000, \$ 3.00$.

BEDER WOOD-(Per.)-This is generally conceded to be one of the very best early varieties for home use or market. It is a splendid grower, making a large number of strong runners. It has a perfect blossom and is immensely productive. Fruit of good size, light red, medium firmness and good quality. One of the best to plant with early blooming pistillate varieties.

I feel that we have not said enough in favor of this variety and that it has been neglected in our desire for something new. It certainly is a much better market berry than a lot of the newer sorts that are given lengthy descriptions and loudly praised. Its worst feature is its color, which is a little too light. I would recommend it as a reliable sort for market purposes.

While this sort could hardly be classed as a firm or hard berry, it has a peculiarly dry or spongy nature which enables shipping it long distances without injury. It is an excellent plantmaker, setting freely and rooting deep; thus being able to withstand drouth better than those sorts not rooting so deeply. If we are to have a cycle of dry seasons, as some predict, this feature is worth consideration. I should like to emphasize what I have said in its favor and again recommend it as a paying market sort.

Twenty-five, $15 \mathrm{c}$; hundred, $50 \mathrm{c}$; thousand, $\$ 2.25$.

HAVERIAND-(Imp.)-This is one of the best early market sorts, and seems to do well in all sections. It makes a thrifty plant growth. Berries are large and of a peculiar longish shape, though very regular and even, holding out well to the end of the season. The color is rather light red, which may be considered a fault by some, but they make such a handsome appearance in box or basket that they nearly all sell for top price in market. About the only weak point I have discovered in the Haverland is that the fruit stems are tall and unable to stand up under the weight of fruit as it ripens, consequently they should be mulched with straw to keep them from the dirt. This peculiarity of growth makes fine picking, as the berries lay out in sight requiring no movement of the vines to find them. Another good point in their favor is the ability to with. stand frost at blooming time often bearing a full crop of perfect fruit when other sorts are badly damaged. There is such a demand for plants of this variety that the supply nearly always fails.

There have been a great many spurious or mixed plants sent out from this section as Haverland; we warrant ours true to name. If you are unacquainted with this sort try a few and see what a fine market berry they are. A little too soft for distant shipment, but they will stand picking before fully ripened and will color up in the crate, after picking. If handled in this manner Haverland will stand shipment as well as any of the larger varieties.

Twenty-five, $20 \mathrm{c}$; hundred, $60 \mathrm{c}$; thousand, $\$ 3.50$.

CRESCENT-(Imp.)-This is a very prolific berry, bearing profusely even under neglect. In growth it is very vigorous and hardy, and produces better if the vines are not allowed to mat. They should be thinned even if the hoe has to be used. Fruit colors on all sides at once. A great cropper; early. This has been rightly termed the lazy man's berry, as it seems to be able to thrive under neglect, although it readily responds to better treatment. This is perhaps the best variety for light and sandy soils.

This variety at one time was the standard market sort for this section, as grown in matted row But with the advent of Warfield the Crescent was dropped by a great majority of growers, as the newer Warfield promised to outclass it as a market sort, being of higher quality. However, of recent years the Warfield does not seem to be giving the satisfactiin it formerly has done and many growers are again turning their attention to the old Crescent.

Stock of this variety has become badly mixed in this locality and I found my own, as well as my neighbors' Crescent so badly mixed with Warfield, and other sorts, that I cut it out of my list entirely last year, sending away for new stock to propagate from, and this season I have a limited amount which I think I can warrant pure.

Twenty-five, $15 \mathrm{c}$; hundred, $50 \mathrm{c}$; thousand, $\$ 2.50$.

IOVETT-(Per.)-No person need hesitate to plant this variety for either home use or market, as it succeeds generally in any soil or locality. It is one of the tough, hardy varieties that will never disappoint the grower. It has a perfect blossom and bears heavily. The fruit is from medium to large size, conical, firm and of good color and quality. One of the best to use as a pollenizer for pistillate sorts.

This is another of the good old sorts which has been neglected for some of the newer ones not nearly so good. J. T. Lovett, of N. J., when he introduced this sort called it "Lovett's Early," and while it commenced ripening a few of its berries quite early, it continued in bearing a long time. this feature discouraging those who had set it thinking it was an early berry. Thus it lost popularity and I think it has never regained the position it should have held only for the mistake of its introducer. Lovett is a good grower of strong and healthy plants, the fruit somewhat resembling the old Wilson. My block of this variety is looking fine-fully the equal of any sort I have. I would advise a trial of it for either home use or market. $25,15 \mathrm{c} ; 100,50 \mathrm{c} ; 1,000, \$ 2.50$.

IADY THOMPSON-(Per.)-This is not a new variety having been grown in the south a number of years and is a very popular market berry in that section. It is described as a bright red berry, shaped almost like a top and of medium large size; the fruit is solid and meaty with an exceedingly rich flavor and pink in color; has extra tall foliage and fruit stalks holding the berries well up from the soil.

It is a deep rooted variety and is one of the best drouth resisters known, seeming at its best in a dry season. Its season of ripening is very early continuing in bearing for a long time and holding its size well to the last.

While this is pre-eminently a southern variety, it will do well in the more northern latitudes especially in dry locations.

Twenty-five, $15 \mathrm{c}$; hundred, $50 \mathrm{c}$; thousand, $\$ 2.50$

KIONDIKE-(Per.)-This is another southern berry, and how noticeable it is that very nearly all of our early sorts are of southern origin. This variety is claimed to be an improvement over the Lady Thompson, being much darker in color, both of foliage and fruit, and is a very solid berry, and dark red to the center.

Without doubt there are more acres of this variety grown for market than of any other sort and it well deserves its popularity. It is a very strong grower making a full row of well developed plants, and is wonderfully productive.

I have only a limited stock to offer this season.

Twenty-five, 20c; hundred, $60 \mathrm{c}$; thousand, $\$ 3.00$. 


\section{MID-SEASON TO LATE VARIETIES.}

BUBACH-(Imp.)-Fruit large and handsome, roundish, conical bright scarlet, moderately firm, of fair quality. Plant a strong grower with a large healthy foliage and very productive. Succeeds on light or heavy soil. Desirable for home use or near market. One of the best. Season early to medium. This is an old standby and is deservedly popular. In plant growth it is vigorous, but does not throw out excess of runners, hence it is best grown in hedge or half-matted row.

This variety is perhaps as well known and as widely disseminated as any grown, and while it is perhaps not as popular as it was several years ago, still we always run out of stock long before the close of the season. While it is hardly firm enough for long distance shipping still it will hold up for ordinary marketing and is one of the largest berries grown.

Twenty-five, $25 \mathrm{c}$; hundred, $75 \mathrm{c}$; thousand, $\$ 4.00$.

POCOIMOKF-(Per.) - The originator says: "Originated near Pocomoke River; was found growing where there had been some Wilson and Sharpless strawberries dumped, and is supposed to be a seedling of the old Wilson crossed by the Sharpless. The berry is round, conical, and resembles the old Wilson, but is much larger. One of the best varieties in existence, not only for its enormous productiveness, but on account of its beauty, adaptability to all soils, its foliage enduring the dry, hot weather (which quality is rare), its large size, its deep red color, its firmness, its high flavor. The plant is a strong, robust grower, with deep roots and lots of them, perfect blossoms and is an enormous yielder of large red berries. It ripens evenly and is one of the best shippers yet produced."

This proves to be one of the very best sorts we have on the list, and I do not hesitate to recommend it either for home or for market.

The above was taken from description given in previous issue of this catalog and I only wish to emphasize what I have formerly said in favor of Pocomoke. I can see little or no difference between this variety and Parsons Beauty, in fact most growers call them identical, consequently I have dropped the Parsons from my list. Pocomoke is not a new or untried sort, but has been fruited in this section for several years and is considered one of the very best.

I have a fine lot of plants of this sort for next spring and hope to be able to fill all orders and would urge all to give it a trial.

Twenty-five, $25 \mathrm{c}$; hundred, $75 \mathrm{c}$; thousand, $\$ 4.00$.

MARIE-(Imp.)-This is not a "new" sort, but has not been very generally disseminated and is therefore "new" to a great many growers. It is a wonderfully firm and fine appearing berry, making it first-class as a market sort. A little too sour for some tastes.

I can recommend it as a promising market variety and urge all to give it a trial.

Twenty-five, $15 \mathrm{c}$; hundred, $50 \mathrm{c}$; thousand, $\$ 3.00$.

WIM. BEIT-(Per.)-From M. Crawford's catalog: "Introduced by us about eleven years ago. We might describe it by saying that it has every good characteristic save one,- it is rather subject to rust. Although its single failing is well known it is extensively planted by a large number for its many excellencies. We have seen it produce berries over nine inches in circumference in sixty days from the time it was transplanted. The plant is very large and sends out plenty of strong runners. It is very productive.

Twenty-five, $20 \mathrm{c}$; hundred, $60 \mathrm{c}$; thousand, $\$ 3.50$.

\section{LATE TO VERY LATE VARIETIES.}

SAMPIE-(Imp.)-This I consider the best of the late sorts yet introduced. The halftone showing a stem of green berries was taken from nature and at a time when most early sorts had finished ripening their fruit, while the Sample were just beginning to color; as I remember, there was only one fully ripe berry on the stem. This tends to show the lateness of the variety. This was not an exceptionally large cluster but just a fair average as taken from a block given ordinary field culture without any manuring or other special treatment. The introducer says: "Large size and fine quality; quite firm; continues a long time in fruit. The berries are large to the last. For the marketman it is the best strawberry ever grown. I have nothing in my grounds that will begin to fruit like it. It will yield as many berries as the Haverland and will average as large as the Bubach. Colors all over at once. A berry that will do that is the best, one yet found. There is not a weak spot in it. Foliage perfect, fruit perfect."

Without doubt Sample is the most popular late sort grown today and we always sell out of this variety early in the season, so I would advise all who want to get the best late strawberry to place their orders early as we are sure to run short.

Twenty-five, $25 \mathrm{c}$; hundred, $75 \mathrm{c}$; thousand, $\$ 4.00$.

STEVENS' IATE CHAMPION-(Per.)-This new late variety originated in New Jersey; seems to do well wherever tested. The originator describes it as follows:

"Very large, fine flavored, bright color, good shipper, a fine bed maker, a heavy yielder, fine foliage, ranging from twelve to fourteen inches high, with a good fruit stem. This berry aver- aged 7,556 quarts per acre in 1902 , netting $\$ 666.96$ per acre; selling as high as 22 cents per quart in New York market last season. It has been tested on all kinds of soil and will grow successfully where any strawberry will grow. It will stand a drouth better than any other berry ever grown in this section.

'Its name, 'Champion,' was given it by a lot of berry growers, some saying it would challenge the world.

"It ripens later than the Gandy Prize, and lasts until the Fourth of July any season. It has never shown any sign of rust. The cap, which is double, has always kept green until the last of the season."

I have grown this variety in a limited way for several seasons and think it fills the originator's claims in a large degree and while it does not grow twelve to fourteen inches in height, it cer. tainly is a very strong and healthy grower and a prolific bearer. I should not class it as of best quality, but for a late market sort it is ahead of Gandy as we grow them here.

I have a very large stock of this variety and shall offer it low and would advise market growers to give this a trial.

Twenty-five, $20 \mathrm{c}$; hundred, $60 \mathrm{c}$; thousand, $\$ 3.50$.

GANDY-(Per.)-Description taken from J. T. Lovett's catalog: "Introduced by me in 1888, and now more largely grown by far than any other variety-beyond doubt there were more quarts of berries of this variety marketed in the United States during the past few years than of all other varieties of the strawberry put together. It ripens late to very late, and the berries are large 
to very large, bluntly conical, of the firmest texture and bright flame-colored-which color they retain until they decay; but in flavor it is rather acid and not of the highest quality. It is very nearly perfect in vigor and growth of plant yet it is but a moderately productive variety, except under high culture and upon very moist land. It originated in a meadow in South Jersey and its peculiarities are its preference for very moist land and the fact that it usually yields more bountifully the second than the first year. Of special value in canning.'

This sort has always been popular as a late market variety, but does not do well on a light sandy soil, and is apt to be disappointing when planted in such location. I have no hesitation in recommending this to all as one of the best late sorts for home use or market. The only fault that I ever heard found with it was its " sh ý bearing" when planted on uncongenial soil.

Twenty-five, 20c; hundred, $\quad 60 \mathrm{c}$ thousand, $\$ 3.50$.

\section{BRANDYWIIE} - (Per.) - This has proved so satisfactory with all who have grown it that it is consequently in large demand. It is comparatively new and of great value by reason of its $\mathrm{p} r$ o d u c t i v en es s, large size, beauty and good quality, which renders it especially desirable for the home garden. The berries are glossy c rim s o n, very handsome, firm and solid, excellent in quality, with fine aromatic flavor.

The berries color all over evenly and retain a good size to the last, ripening in succession and every berry maturing fully. Plant is remarkably vigorous, hardy and exceedingly productive, and its foliage is large, clean and healthy. The amateur will delight in such a superb variety, which with his good soil and careful culture will give him magnificent returns. Mid-season to late. It is also an excellent pollenizer for mid-season to late pistillates.

Twenty-five, 20c; hundred, 60c; thousand, $\$ 3.50$.

UNCLE SAM-(Per.)-This new seedling berry originated in Ohio and is a promising sort. The introducer's description is as follows: "Large to very large, will average larger than Bubach; ripens with the Bubach, but has a much longer season, a perfect bloom and is much more prolific. Have picked Uncle Sam berries as early as May 22 and on July 5 , of the same year, picked berries one and one-half inches in diameter. There are no green ends, buttons or nubbins on first year's fruiting. Color red, quality delicious, foliage strong and vigorous; berries of Uncle Sam can be picked two weeks after most other berries are gone."

This variety has never been "boomed" as a great many others have consequently is not very widely disseminated. I have fruited it in a small way for a number of years and have found it a very satisfactory sort, always making a good row of strong and healthy plants and giving a heavy yield of very handsome fruit late in the season.
It is a strong staminate and is a good pollenizer for late pistillate sorts.

Twenty-five, 25c; hundred, $75 \mathrm{c}$; thousand, $\$ 4.00$.

NORTH SHORE-(Per.)-“This rather new variety is rapidly gaining in favor. The plant is of good size, a vigorous grower and a prolific yielder. From our note book we describe the fruit as very large, rich red throughout, core and all. Fine, close seeds, red and yellow. Heart pithy, sometimes hollow. Excellent to handle. High flavor. Most fragrant of all. July fourth, large, good, handsome. Season medium to late."

Twenty-five, 20c; hundred, $60 \mathrm{c}$; thousand, $\$ 3.50$.

ABINGTON-(Per.)-This new strawberry was introduced by Lester Blanchard, of Abington Mass., from which town the berry seems to have taken its name. Mr. Blanchard, in his description, says that it was found on his farm as a chance seedling in $\mathrm{t} h \mathrm{e}$ spring of 1895 . A strong staminate blossom, making it a good pollenizer for late pistillate sorts. A strong grower and a good plant maker. $\mathrm{T}$ h e introducer claims the berries are of a large size, as large a s $\mathrm{B} \mathrm{u}$ bach and better shape and color, being a bright red, very firm and of good quality; also, that in ten years of fruiting it has never failed to produce a good crop of large berries being more productive in matted row or under poor culture than any berry of its: class. Its fruiting season is long, making it a good variety to set with late pistillates.

Twenty-five, $20 \mathrm{c}$; hundred, $60 \mathrm{c}$; thousand, $\$ 3.50$.

AROMA-(Per.) - "For several years this berry has been growing rapidly in favor, and for the last three or four years has been the leading late variety in this section of the country. It has largely supplanted the well-known Gandy as it seems to be suited to a greater variety of soils, and probably one-half to three-fourths of the acreage planted in southwest Missouri this season will be of the Aroma. While it commences ripening a little earlier than Gandy, it generally lasts as long, is much more productive, and there is no berry that outsells it on the market. A good plant maker, and free from rust. Fruit very large, roundish in shape, rarely misshapen and deep glossy red in color. If you have not tried this variety, do so, for we are satisfied you will be pleased."

Above description is copied from a Missouri catalog.

The Aroma seems to be very satisfactory in that section, but has not done as well with us of late, its weak point seems to be a shortness of root growth causing it to be easily injured by extreme cold of our winters.

We have a limited supply of plants for coming season which we will protect for the winter and will be in good shape.

Twenty-five, $20 \mathrm{c}$; hundred, $60 \mathrm{c}$; thousand, $\$ 3.50$. 


\section{RASPBERRIES.}

CUITURE-Any soil that will produce good field crops is suitable for raspberries. Pulverize the ground thoroughly and manure liberally. The red or sucker variety should be planted in rows six feet apart, with the plants three feet apart in the rows, requiring 2,400 plants per acre.

The cap varieties for field culture should be planted in rows seven feet apart with the plants three feet six inches apart in rows; requiring 1,725 plants per acre. In garden culture plant four feet apart each way.

EARIY IING-This new variety is coming to the front rapidly. Among its many points of excellence are these: Extreme earliness, canes strong growing and hardy, never having winter killed since its introduction. Very prolific bearer of large, firm and bright colored fruit. I would recommend it as best early red raspberry.

My stock of plants is very limited.

Twenty-five, 35c; hund r e d, \$1.25; thousand, $\$ 10.00$.

\section{UT F B T T} Or IIT - A remarkably $\mathrm{s}$ t $\mathrm{r}$ o $\mathrm{ng}$, hardy variety. Stands the northern winds and southern summers equal to any. Berry very large, sometimes measuring three inches around; conical, $\mathrm{rich}$ crimson, very handsome, and so firm they can be shipped hundreds of miles by $\mathrm{rat}$ in good condition. Flavor is rich, sweet and luscious. The leading market variety for main crop. Without doubt the most popular red raspberry known to the fruit growers of today, and it certainly leads all others in points of productiveness, quality and appearance, and by long odds in acreage grown.

Twenty-five, $30 \mathrm{c}$; hundred, $85 \mathrm{c}$; thousand, $\$ 7.00$.

MIIIER RED RASPBERRY-The bush is a stout, healthy, vigorous grower, not quite so tall as the Cuthbert, but rather more stocky and dwarfish. It is well cal-

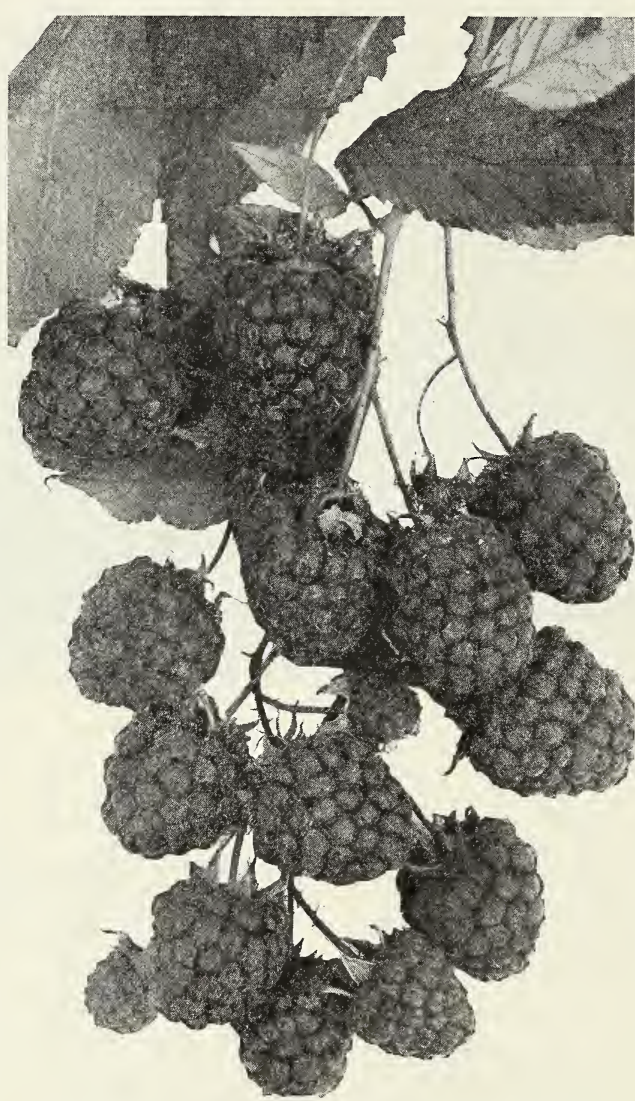

CUTHBERT, OR QUEEN OF THE MARKET strong points of merit it stands unequaled and alone. A variety that is at once perfectly healthy in root and foliage, and hardy, coming through our most severe winters in prime condition; a strong, 'not tall and slender,' but a sturdy grower, throwing out many laterals and fruiting to the tips and from every lateral, a sight to see. An immense cropper, far outyielding any red raspberry we have ever known while the fruit is extraordinarily $\quad l$ a $\mathrm{rg}$ and handsome, firm and of the highest quality."

Above is the originator's description. I have fruited this variety sev eral seasons in a small way and in the past have been somewhat disappointed in its behaviour. Its worst failing being that it is apt to color be fore fully ripe and wil not leave the stem until it is fully ripened, causing trouble in picking until one becomes accus tomed to this feature.

In trying to pick it before it was fully ripe we have called it inclined to crumble, and have been disposed to condemr this as a very bad fea ture. However, the past season we had a small block of Eaton set on heavily manured soil, and the berries were very large, of bright color, and kept their shape in the box as well as any large berry, yielding a heavy crop for first year fruiting.

We have a very limited stock to offer for coming season.

Dozen, \$1.50; twentyfive, $\$ 2.50$; hundred, $\$ 7.50$. which it treme hardiness, as productive as any; one of the earliest to ripen; an excellent shipper; of good quality and attractive color.

Twenty-five, 25c; hundred, 75c; thousand, $\$ 6.00$.

THOMPSON'S IARIY-One of the best early varieties. Plant a good grower and hardy. Commences to ripen before strawberries are gone. A very profitable early variety to grow for market.

Twenty-five, $25 \mathrm{c}$; hundred, $75 \mathrm{c}$; thousand, $\$ 5.00$.

TER EATON-"A new red raspberry and is entirely distinct from all other varieties. In character of growth, in size, color, firmness, quality and yield of fruit; in length of season, and in all
Steele, Mo., April 26, '09.

C. E. Whitten, Bridgman, Mich.

Dear Sir:-I received my berries and grapes the 17 th inst., and am highly pleased as I set out the 500 strawberries the day I received them and there is only one out of the lot that is not growing nicely. They were the finest plants that I ever saw, with the best roots. And as to my grapes I see no reason why they shouldn't grow as they also had fine roots and I can conscientiously recommend your strawberries and grapes to my neighbors which I will do.

Yours very resp't, JOHN R. KELLEY. 


\section{PURPLE CAP.}

COIUMBIAN-The Columbian is a variety of the Shaffer type, of remarkable vigor and productiveness. It is hardy and propagates from tips. Fruit very large, often an inch in diameter, shape somewhat conical, color dark red, bordering on purple; adheres firmly to the stem and will dry on the bush if not picked; seeds small and deeply imbedded in a rich, juicy pulp with a distinct flavor of its own, making it a most delicious table berry.

In my estimation this is the most valuable purple cap yet produced, as it is more hardy in cane

\section{"HAYMAKER"}

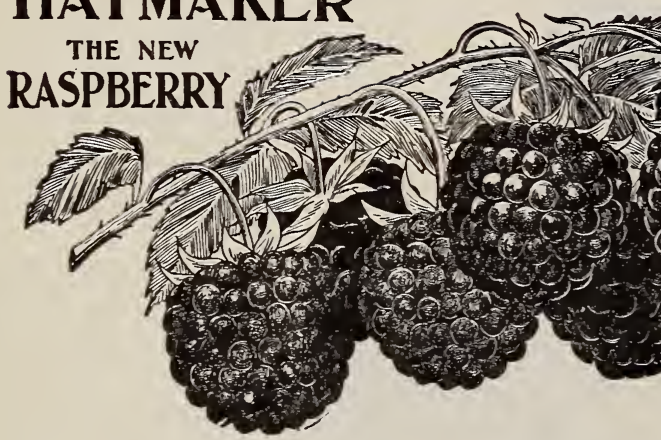

and certainly more prolific, and fruit of larger size than any other sort I am acquainted with.

Twenty-five, $60 \mathrm{c}$; hundred, $\$ 2.00$.

CARDINAI- "This is a new variety of Shaffer type and is claimed to be superior to either Shaffer or Columbian, both in hardiness of cane and productiveness. It originated in Kansas and the introducer claims it has stood a temperature of thirty-five degrees below zero without injury. It also withstands drouth and heat as well, holding its foliage, which is described as thick, short, broad and deeply wrinkled, dark green in color, until the severe cold of December. It is a very strong grower, with bright red bark and very few small thorns. It propagates from tip same as a black cap. The berries large, dark red, firm as to texture, with an agreeable, pure, rich flavor which is brought to its highest perfection when canned or cooked in pies. Their season is rather late and they hold on well."

After fruiting this sort I am somewhat disappointed in its behavior. It is not as prolific as Columbian and not much different as to quality. It seems to partake a little more of the red raspberry type than either Shaffer or Columbian. This will meet the wants of those who object to the suckering of red varieties.

Twenty-five, 60 ; hundred, $\$ 2.00$.

HAYMAKER-“The Haymaker is a purple cap, not so dark as Columbian or Shaffer, and much larger and firmer than either of those varieties, never crumbles and stands up well for shipping. Sample crates have been shipped to distant points with entire satisfaction. It is a berry to grow for either home use or market. The originator has found it the most profitable berry ever raised for market, and has never yet been able to supply the local demand. So much of a favorite has the Haymaker become that local growers have said that it ruined the sale of other rarieties. Very popular as a canning berry."

Abore is a part of the introducer's description. I have fruited Haymaker for several years and do not find it preferable to Columbian. Possibly the appearance of Haymaker is a little finer as picked, having less of "bloom" which hurts the appearance of Columbian somewhat, but in hardiness of cane, and productiveness the Columbian will lead.

Twenty-fire, 60c; hundred, $\$ 2.00$.

\section{BLACK OR CAP VARIETIES.}

MUNGER - “A seedling of Shaffer's Colossal. Late; larger than Gregg, of better quality, somewhat firmer, making it a better shipper, and a few days later in ripening. Color jet-black. Canes vigorous, very productive. The best and most profitable blackcap raspberry in cultivation."

This is not a new sort, but is the second time I have cataloged it. It may seem strange to some that a seedling of Shaffer Colossal-a purple berry-should be a blackcap, but when we remember that Shaffer is a hybrid between a red and black raspberry the parentage is accounted for. You will notice that the fore part of this descriptior is copied from another catalog; I am not ready, as yet, to say that any variety is the best ever.

I do think, however, that this is a good one and that it has points that are superior.

Twenty-five, $40 \mathrm{c}$; hundred, $\$ 1.25$; thousand $\$ 10$

GREGG.-The Michigan Experiment Station says of this variety in their 1903 report: "Gregg is the most popular blackcap grown and adapts it self to almost any condition. With good culture there are few superior. The canes are strong, productive, but not quite hardy; berries are attractive and of choice quality. Twelve berries weighing one ounce as compared with Ohio thirty to the ounce."

My experience is that Gregg is quite hardy on
Well drained soil, but does not love wet feet and winter kills badly on wet ground. The berries are covered with a whitish blue bloom which in its first dissemination was mistaken for mould or mildew and hindered the sale of fruit on the market: but since becoming better known this sort is very popular in all sections, and I do not hesitate to class it as the best late market sort.

Twenty-five, $35 \mathrm{c}$; hundred, $\$ 1.00$; thousand, $\$ 8.00$.

KANSAS-For a good second early blackcap there is nothing better than this. It possesses all the valuable attributes of a profitable market sort, and its large size and attractive appearance in sures for it always a ready sale and good prices. The fruit is nearly as large as the Gregg and with much less bloom, handsome, firm and of fine quality. Its canes are of strong growth; entirely hardy and prolific; with tough, healthy, clean foliage. Its season is about second early-later than Souhegan, but much earlier than Gregg.

Twenty-five, $35 \mathrm{c}$; hundred, $85 \mathrm{c}$; thousand, $\$ 7.00$.

CONRATH-Resembles Gregg in many ways, but is much earlier and is firm, sweet and goodmaintaining its large size to the last picking. The canes are of ironclad hardiness, very prolific, and make a strong healthy growth. It ripens early.

Twenty-five, 35c; hundred, $\$ 1.00$; thousand, $\$ 8.00$ 
CUMBIFIAND-This has been named the "Business Blackcap" by the introducers, and has been loudly praised by all who have grown it. It is a very large berry of fine flavor, rich and sweet, and of jet black color with slight bloom. The cane is of extreme hardiness, very strong growing and free from anthracnose. In other seasons I have praised this sort as the best black raspberry for either home use or market, but the past season was very wet and rainy at picking time and while all late varieties were more or less water soaked, Cumberland seemed about the poorest both as to flavor and firmness. If this had been my first and only experience with the variety I should have condemned it as worthless, but we know that in ordinary seasons it is fine.

The above description was taken from a former edition of this catalog and I can only repeat that this variety seems to still hold its popularity as one of the best blackcaps.

Owing to favorable $\mathrm{g} r$ o w in $\mathrm{g}$ conditions we have a good stock of strong and wellrooted tips and have lowered $\mathrm{th}$ e $\mathrm{price}$ somewhat on all blackcap varieties.

Twenty-five, $\quad 40 \mathrm{c}$; hundred, $\$ 1.25$; thousand, $\$ 10.00$.

HOOSIFE - "The $\mathrm{H}$ o o s i e r raspberry originated $\mathrm{with}$ u s eight years ago and has proven a wonder, surpassing all others

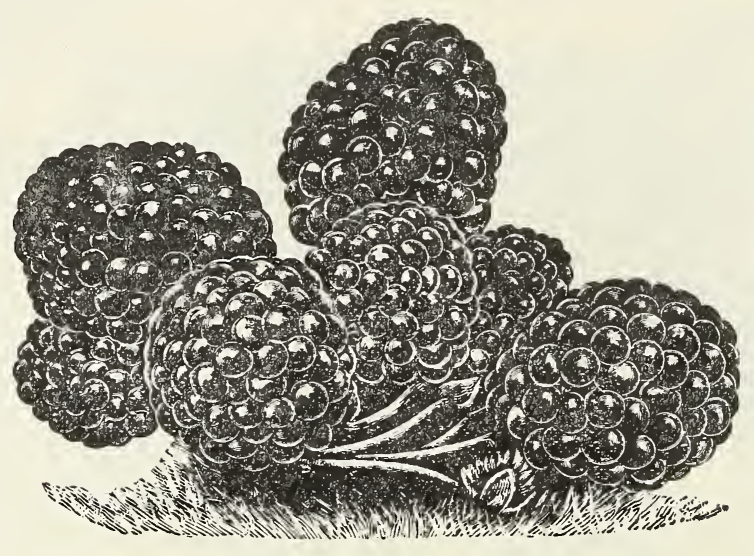

CUMBERLAND. here and is a drouth resister, and is absolutely proof against anthracnose and other raspberry pests.

"The fruit sells for double the price of any other variety. It is a pocketbook filler.

"What we say is backed up by our local banks, newspapers, business men, county officers and by prominent commission merchants of Chicago and other cities."

I received plants of this variety from the introducer, Alva G. Gray, of Indiana, last spring and am much pleased with their manner of growth and the healthful appearance of the canes.

I have not seen this sort in fruit and can only give the introducer's description. I can furnish a limited amount of extra fine plants.

I offered this untried sort to my patrons last spring givin $\mathrm{g}$ the foregoing "originator's description;" but after fruiting it the past season in a small way I am very much disappointed in it as it surely failed to "make good" Mr. Gray's claims. Its season was about with Kansas and ripened its crop very quickly $n$ ot making the long season that he claims. Nor was the size and quality of fruit very different from Kansas with me. However, it c e rtainly is a very thrifty and healthy grower making a strong bush with lots of in every point of excellence. Perfect, hardy and fully tested in every state in the Union and throughout Canada; does not winter-kill, and will mature a full crop even to the tip of the canes.

"This berry begins to ripen a full week ahead of the Cumberland and continues a week longer, is firmer and better flavored, jet black and glossy, very productive, averages 1,200 gallons per acre laterals and showing scarce any trace of anthracnose, that worst enemy of all black raspberries. I have several thousand tips of this sort, of my own growing which are very fine and I will furnish to those who wish to test this variety at a low figure.

Twenty-five, 40c; hundred, $\$ 1.50$; thousand, $\$ 12.00$.

\section{DEWBERRIES.}

There is great diversity in methods given for the cultivation of this fruit. Some say train to stakes or wires; others to let lie on ground and grow at will, while still others advise cutting off all the growth to the ground immediately after fruiting, then allowing the bush to form for the next season's crop. I have never tried this latter method, but the Lucretia is such a rampant grower (often running 12 to 15 feet) that I have no doubt it would make plenty of wood before the growing season ended. This would be the easiest way to grow, if successful, as it would be very little work to clean out a field after fruiting as compared with having to work amongst the new vines if they should be left from early spring. Of course, the ground would have to be kept cultivated well while this growth was being made especially in dry location or season.

IUCRETIA-This is counted as the standard of all dewberries, is earlier than the earliest blackberry and as large as the largest of them. The canes are of great hardiness and exceedingly prolific, thriving everywhere, of slender trailing habit and entirely free from disease and insect attacks. The fruit is large and handsome, jet black, rich and melting; ships well and keeps well. We picked these berries the past season with the raspberries, bringing $\$ 2.00$ to $\$ 2.50$ per sixteen quart crate in Chicago market. I would advise my friends all to try at least a few of them in their gardens.

Twenty-five, $35 \mathrm{c}$; hundred, $\$ 1.00 ;$ thousand, $\$ 8.00$.

Dayton, O., April 22, 1909

C. E. Whitten

Dear Sir:-Received your plants April 17, 1909, in very good condition. Many thanks to you for promptness.

Yours respectfully

CLYDE S. NUMMA, R, R. I.
C. E. Whitten,

Mt. Vernon, O., April 27, '09

Dear Sir:-Rec'd the plants of you and they are in as good a shape as one could ask for. Thanking you for same, I remain, Yours,

J. M. COWARD. 


\section{BLACKBERRIES.}

Should be planted in rows six or seven feet apart and three to five feet in the rows. Keep the ground light and rich. Pinch the canes back when they have reached the height of from two to three feet.

Our blackberry plants are mostly "sucker" plants, except where marked "Root Cutting." These "sucker" plants are dug from between fruiting rows, or where "root cutting" plants have been taken leaving the broken roots in the ground which have thrown up shoots, or suckers as we term them. When properly dug with cross roots these make first class plants and prove about as satisfactory as, and at a much lower cost, than "root cuttings."

EIDORADO-I, head the list with this variety as I think it is entitled to that distinction. It having proved to be the hardiest in cane of any of the larger berries that I have tested. It is free from Orange Rust or other disease, medium early in season, especially adapted to the home garden as it is large, juicy, and of good flavor and without the hard core of some varieties. It will also sell well in market, as it is jet black and holds its color well. This is becoming a very popular sort and the supply of plants is limited, not nearly enough to supply the demand.

I recommend it as the very best hardy sort we have grown in this section. Owing to shortage of plants this season we will have to advance the price somewhat, although we are still lower than most of the wholesale nurseries on this variety.

Twenty-five, $60 \mathrm{c}$; hü dred, $\$ 2.00 ; \quad$ thousand, $\$ 17.50$.

WITSON'S FARIY Of good size, very early, beautiful dark color, of sweet excellent flavor and very productive. Ripens the whole crop nearly together.

This variety is tender in cane and in northern latitudes will have to have winter protection. This is not such a serious job as some might think; if taken just before the leaves drop in fall and wood is still somewhat green, the canes in the hill can be gathered together and bent to the ground and tips covered with enough earth to hold them in this position. Always bend toward the prevailing winds as this will tend to hold the snow, if any. Commence at the far end of row and bend from you, but in line with the row, con- tinuing this with each hill, letting top of one overlap the root of the previous one. Unless very dry few canes will be broken by this bending. After all are bent down, cover rows with strawey manure, or other litter, using enough to cov er from sight; then, using a medium size turning plow with one horse, turn two furrows to each side of row, being care. ful not to plow deep enough to cut roots. This is usually sufficient, but it would be as well to go over the field with shov el covering any canes exposed. We do not cover to keep from freezing, but to prevent sun and wind drying out too much, thus evaporating the sap, or life fluid from canes. This is the cause of injury more than intense cold. In the south this variety is hardy enough to stand vithout protection and is sertainly on of $\mathrm{t} h \mathrm{e}$ most profitable sorts for market. Our plants are No. 1 Sucker Plants.

Twenty-five, 35c; hundred, $\$ 1.00$; thousand, $\$ 7.50$.

FARIY KING-An extra early blackberry, exceedingly hardy variety of great merit. Needs always producing large no winter protection, always producing large Snyder and very prolific. It is much larger than Early Harvest and its delicious sweetness renders it of special value for home use or market. It is also free from double bloom and other disease, and will go through hard spring frost in blossoming time without injury. Those who have tried this variety are well pleased.

Twenty-five, 35c; hundred, \$1.25; thousand, $\$ 10.00$.
Broken Bow, Custer Co., Neb., May 8. C. E. Whitten,

Dear Sir:-The plants came in fine shape Wed. They stood their longl trip finely.

\author{
W. DEMING.
}

Lebanon, Ind., May 1, '09.

Dear Sir:-Strawberry plants, order No. 1,948, just received. They seem to be in fine condition. Accept my thanks.

Respectfully,

(Mrs.) KATE L. KELSEY.
New Castle, Pa., April 27, '09.

Dear Sir:-I received plants all $O . K$. and are the best plants I ever saw shipped.

Yours resp't,

\section{O. C. STINPLE.}

Chillicothe, Ill., May 10, '09.

Mr. C. E. Whitten, Esq.

Sir:-Received plants in good order. Finest plants I ever bought.

Yours,

M. HAMPTON. 


\section{CURRANTS.}

A cool moist location is best for this fruit, and for this reason succeeds admirably when planted by a stone wall or fence; being benefited by partial shade. Plant in rows four feet apart, and the plants three feet apart in the rows. Keep the ground mellow and free from weeds and grass, using fertilizer copiously. Mulching is necessary for the best returns.

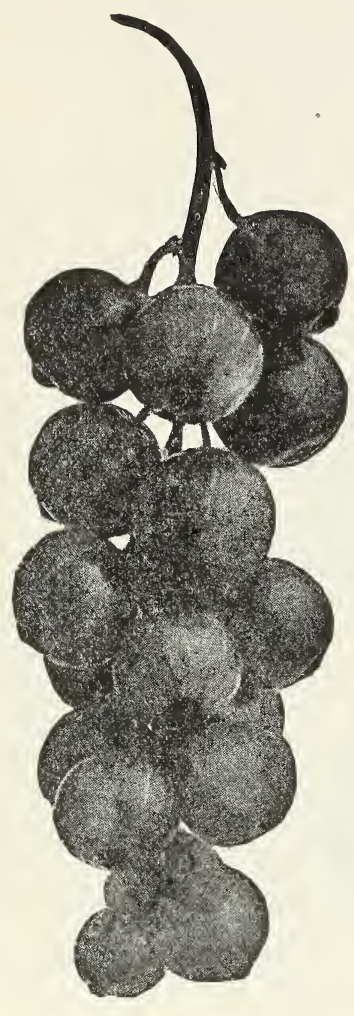

PERFECTION.

PERFECTION-This new currant was originated by C. G. Hooker, of New York State, by crossing the Fay's Prolific with the White Grape Currant. It has the large size of the Fay with the extra good quality and great productiveness of the White Grape. The color is beautiful bright red, and is less acid and of better quality than any other large currant in cultivation. Perfectly healthy, and a vigorous grower, and in fact the best currant for home use or market purposes under cultivation today. In July, 1901 , it was awarded the $\$ 50.00$ Barry gold medal by the Western New York Horticultural Society after a trial of three years. It also received the highest award given any new fruit at the Pan-American Exposition, and it also received the only gold medal awarded to any currant at the St. Louis Exposition. It has also received a great many testimonials from the highest sources in this country. We show a natural size cluster of this fruit reproduced from a photograph taken at the New York Experiment Station. I think all who want a fancy fruit of this sort will do well try try a few. Two year plants.

Twelve, $\$ 1.75$; twenty-five, $\$ 3.00$; fifty, $\$ 6.00$; hundred, $\$ 11.00$.

WIIDER - A remarkable variety, for which we predict great popularity, both for table and market. One of the strongest growers and most productive. Bunch and berries very large, bright attractive red color, even when dead ripe; hangs on bushes in fine condition for handling as late as any known variety. Compared with the celebrated Fays is equal in size, with longer bunch, better in quality, with much less acidity; ripens at same time, continues on bush much longer; fully as prolific, in some trials largely outyielding it. Recommended by our Experiment Station as the best red currant. Strong one year plants.

Dozen, $75 \mathrm{c}$; hundred, $\$ 4.00$.

IONDON IMARKET-Of English origin. As compared with Victoria, it is larger, more productive, much stronger grower, less infested with borers and retains its foliage until frost comes. It has produced twice the amount of fruit the Victoria did under same conditions; a very strong and upright grower. Strong plants. Dozen, $75 \mathrm{c}$; hundred, $\$ 4.00$

WHITE GRAPE-Very large, yellowish white, sweet or very mild acid; excellent quality and valuable for the table. The finest of the white sorts. Dozen, $75 \mathrm{c}$; hundred, $\$ 4.00$.

CHERRY-Very large, deep red, rather acid; bunches short. Plants erect, stout, vigorous and phroductive.

Dozen, $75 \mathrm{c}$; hundred, $\$ 4.00$.

FAY'S PROIIIXC-Perhaps no other currant has received so much praise as has the Fay. It is very large and always sells well and at high prices. It does better on heavy clay soil well manured and thoroughly cultivated than on lighter soils. Dozen, $75 \mathrm{c}$; hundred, $\$ 4.00$.

\section{GOOSEBERRIES.}

The same soil and conditions best adapted to currants will be appropriate for gooseberry culture. The American varieties of gooseberries are among our hardiest plants. All of the standard sorts of the present day are cultivated forms of a native species natural to the upper Mississippi Valley and in this region the cultivated sorts seem to reach their highest development. Clean culture should be given until the plants are well established, usually about the third year; after this they may be permanently mulched. As the best fruit is borne on the two and three year-old wood, a certain amount of pruning will be necessary to encourage a strong growth of canes and in the removal of the older wood after bearing.

DOWNING-This is without doubt the best gooseberry for general cultivation that is offered today. It is an American or Native seedling, not an English sort. The latter are very hard to grow successfully in this climate on account of weak foliage which is very susceptible to mildew. When this disease attacks the gooseberry it causes the foliage to drop before the berries are fully grown and materially injures the crop. Downing is a yellowish green sort and of good size, being a strong growing bush and a very prolific bearer. Plants of all varieties of gooseberries are in light supply and in very good demand and the price is high.

Dozen, $\$ 1.50$; twenty-five, $\$ 2.50$; hundred, $\$ 8.00$.

HOUGHTON-An enormously productive and always reliable old sort; of vigorous yet rather slender, spreading growth, not subject to mildew. Fruits of medium size, smooth, pale red; tender and good. Dozen, $\$ 1.00$; twenty-five, $\$ 1.75 ;$ hundred, $\$ 6.00$.

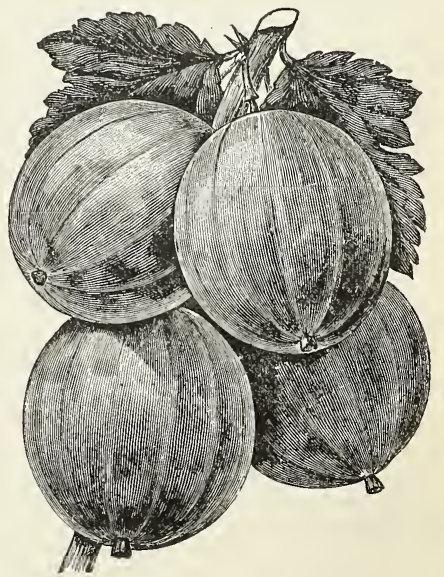




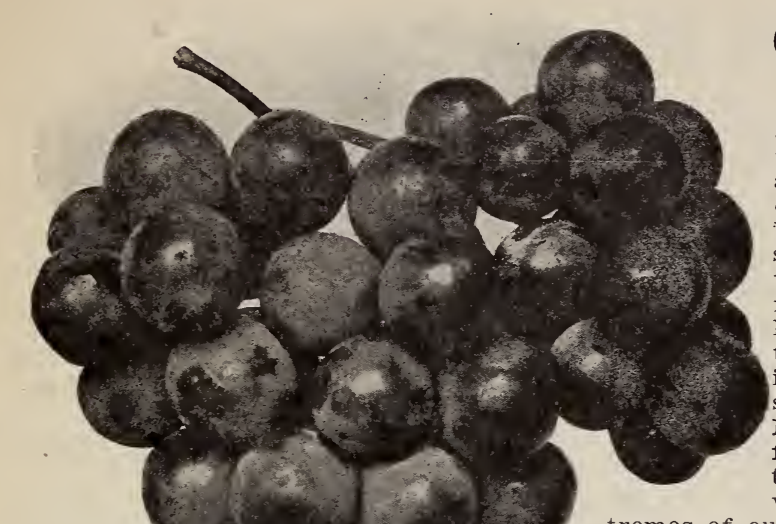

\section{GRAPE VINES.}

The grape is one of the easiest fruits to grow and should be in all collections. When once well established vines will continue in bearing a long time with very little care other than the cutting back of the extra growth which should be done in winter or very early spring (before sap starts to circulate). This pruning is essential to the healthy growth of the vine and its fruitfulness. The grape is fast becoming a leading fruit in our section of Michigan and there is no reason why it should not be grown in many other sections of our country. With such hardy varieties as Concord, Worden and Niagara, no one need be without at least a few for the home use, as the vines can be taken off the trellis for the winter, and if covered lightly with some kind of mulch will stand the extremes of our northern climate. Owing to the very heavy demand and a material shortage of stock for this season the prices are somewhat higher than in recent years. My vines are all New York grown and will be first class, and of grade represented.

NIAGARA-(White)-Vine hardy, an unusually strong grower; bunches very large and compact, sometimes shouldered; berries as large or larger than Concord; mostly round, light greenish white; semi-transparent, slightly amber in sun, skin thick but tough and does not crack; qual-

CONCORD.

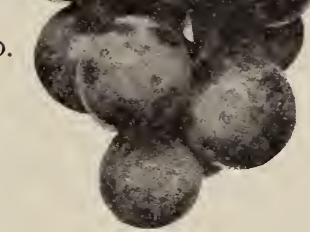
ity good; very little pulp, melting and sweet to the center.

First class one year plants, dozen, $60 \mathrm{c}$; hundred $\$ 4.00$.

CONCORD-A large, purplish, black grape, ripening about the middle of September; vines remarkably vigorous and free from disease; the standard for productiveness and hardiness all over the country. One year, No. 1: Dozen, 50c; hundred, $\$ 2.50$. Two year, No. 1: Dozen, 75c; hundred, $\$ 4.00$

WORDIN-A splendid, large grape of the Concord type, but earlier, larger in bunch and berry, and of a decidedly better quality; vine hardier than that old standby and every way as healthy. A very popular sort, planted largely for the market; next to Concord in number used.

Fine one year plants: Dozen, 60c; hundred $\$ 3.50$. Two year old: Dozen, 85c; hundred, $\$ 4.50$.

MOORI'S FARIY-A black grape. Bunch large, berry round, quality better than the Concord; vine exceedingly hardy. Its earliness makes it desirable for an early crop, and more particularly adapts it for New England and the northern portion of the Cnited States, maturing as it does ten days before the Hartford and twenty days before the Concord. No. 1, one year: Dozen, 75c; hundred, $\$ 4.00$.

BRIGHTON-(Red)-Perhaps the best red grape in cultivation. Bunch large and compact, a strong grower and very productive; quality good. Fine two year plants. Dozen, $\$ 1.00 ;$ hundred, $\$ 5.00$.

\section{ASPARAGUS ROOTS}

When planting asparagus roots, set four to six inches deep, and about 12 inches apart in the row, covering with only three inches of soil at first, and filling in the trenches as the plants grow.

The asparagus bed is apt to be neglected in the early fall. Before the 1st of September the tops should be cut and the bed or field cleared of weeds. It is highly important that all the seed should be taken off, as the greatest enemy the asparagus has in the way of weeds is asparagus, and it is almost impossible to get clear of superfluous plants, when once established. When this work is finished, cover the bed to the depth of three inches with coarse manure, which will not only enrich the soil, but it will keep out the frost, which is highly essential.

The first work in the spring should be to remove all the covering except the fine manure, which should be carefully forked in, so that the crowns will not be injured by the tines of the fork. Forking the beds should not be neglected, as the early admission of the sun and rain into the ground induces the plants to throw up shoots of superior size. Another step in the right direction is to keep the ground entirely free from weeds the entire season, as these take from the plants the strength required for their own growth and the asparagus needs it all.

PAIMETTO - A valuable new variety and is being planted very largely. It is nearly twice the size of Conover, fully as early, and as productive. The flavor is excellent.

Hundred, $75 \mathrm{c}$; thousand, $\$ 4.00$.

CONOVIR'S COIOSSAI-The old standard and popular variety, a good producer; of large quick growth and superb in quality.

Hundred, 75c; thousand, $\$ 4.00$

\section{RHUBARB OR PIE PLANT}

This deserves to be ranked among the best early products of the garden. It affords the earliest material for fine pies and fresh table sauce, continues long in use, and is valuable for canning. Make the ground rich and deep, as recommended for asparagus. Plant four feet each way.

MYATT'S IINNAIUS-Those who have never grown this variety, which is of superior quality, will hardly recognize the old "Pie Plant." It is an early, tender variety, without being in tho least tough or stringy, with a mild, sub-acid flavor.

Good strong roots, $5 \mathrm{c}$ each; dozen, 50c; hundred, $\$ 3.00$. 


\section{INSTRUCTIONS TO PURCHASER}

MIY IOCATION-I am located in southwestern Michigan, about fifteen miles south of St. Joseph, near Lake Michigan, in what is known as the "Great Fruit Belt."

BAIIROAD CONNICTIONS are good. Our line of road, the Pere Marquette, runs mail and express trains direct to Chicago; time about three hours. Within fifty miles this line connects with the great trunk lines, east, west, north and south.

MAIJ ORDERS-I can ship strawberry plants by mail when so desired, and on small amounts for long distance this is much the cheaper transportation, but not so safe as express, as the mode of packing is of necessity different; not having the chance for ventilation, plants are more likely to heat enroute.

I much prefer express shipments and must decline any large orders to be shipped by mail.

BY EXPRESS-This is the safest way to ship live plants, as it makes fast time with the least liability of delay. Sometimes when transferred to another company the charges seem rather high, but when the nature of the service is considered it is really the cheapest in the end.

We have only the United States Express Company; however, we find little difficulty in reaching most of our customers by this company and its connections.

All express companies now bill nursery stock at "General Special" rate, being a reduction of twenty per cent. from the merchandise rate, also making it a "Pound" rate with a minimum charge of thirty-five cents.

We can also get a low rate on long distance shipments of eight cents per pound, with a limit of ten dollars in valuation for each shipment. This is of considerable benefit to our customers west of the Rocky Mountains, where the rate is often ten or twelve dollars per hundred pounds.

IRIIGHT-Early in the season I can ship by reight with comparative safety, but there is a possibility of delay and consequent loss. Parties ordering stock shipped by freight will have to take the risk, as I cannot be responsible for loss, if any, on stock shipped in this manner.

I do not undertake to guarantee safe arrival by any of these modes of transportation, as I have no control of stock after it leaves my hands; however, it is to my interest, as well as the interest of my customers, to have stock reach the purchaser in good condition, and I shall always endeavor to so pack and forward goods that they may prove satisfactory.

IMY PACKING is done in the best possible manner and under my personal care. I use light crates or baskets with plenty of moss for packing strawberry plants and barrels and boxes for other sorts, making no charge for the work or package. My long experience in this line gives me a decided advantage in the matter of safe packing. I also have experienced help who have worked with me several years. Of course, we do not claim infallibility, and are always ready to make reparation where at fault.

Shipping season begins about April 1st, or possibly last week in March, and continues until about 1st to 10th of May.

TERMS-One-fourth cash with order, balance before stock is shipped. Or I will ship C. O. D., if one-half of the amount accompanies the order and purchaser will agree to pay return charges on the money.

REMITIAANCES may be made either by New York or Chicago idraft, postoffice or express order or where none of these may be had, by registered letter.
RATES-Fifty plants of one variety at hundred rates; or three hundred plants of one variety at thousand rates. When an order amounts to $\$ 10.00$ or over, it may be counted at the thousand rate, regardless of number taken. No order booked for less than $\$ 1.00$

MY PRICES are as a general thing very low, but on large lists we are sometimes able to give better rates and invite all wanting large lots to write for estimates.

By large lots I mean a quantity; ten to twenty thousand and up.

Do not write for special prices on two or three thousand.

ORDER BIANIRS-Use the order blank enclosed when ordering, being careful to write your name plainly, giving Postoffice, County and State, and do this every time you write. Also keep a copy of your order yourself. Be particular to say how goods are to be sent, whether by mail, express or freight.

All orders are acknowledged immediately upon receipt. If you do not receive an acknowledgement in a reasonable time, write again.

WHEN TO ORDER-Early, by all means. The rule generally is, "First come, first served," also the early orders find full stock, while later some varieties are liable to be exhausted. Orders are filled in rotation as received, except sometimes our southern patrons are ready to set in advance of those further north; these orders we usually crowd first and get them out as soon as frost is out of the ground in spring.

Our customers will please remember that the time for filling orders is short, and it would facilitate our work greatly if orders were sent before the rush. This is also an advantage to our customers, for they get what they order, no varieties being sold out. To encourage these early orders I will make this offer:

PREMIUM OFFrR-On all orders at catalog rates received during January and February with cash in full, I will allow a cash discount of 5 per cent., or for every dollar sent during these months you may order additional stock to the amount of ten cents. (See inside front cover of this catalog for other premium offers.)

SUBSTITUTION-In ordering, please state whether I shall substitute some other variety in case the kind ordered should be exhausted. If not forbidden I claim the right to substitute something of equal value, but always label true to name. I always aim to substitute sort similar in quality and season and always something listed at equal or higher rate.

GUARANTEE AND CONDITION OF SAIEWhile I take great pains to have stock true to name and hold myself ready upon proper proof to refund money or replace any that proves untrue, it is mutually greed that I shall not be liable for a greater sum than the amounts paid for such stock.

Every order received for articles named in this catalog will be received and executed on the above conditions only, and with the distinct understanding and agreement on the part of the purchaser that I shall in no case be liable for a greater amount than the sum originally paid to me for the stock in question.

REFRENCES-I refer to the United States Express Agent or Postmaster at Bridgman; Union Banking Company, St. Joseph; or Bradstreet's Commercial Reports, as to my standing and reliability. Parties writing any one of the above, please enclose stamp for reply. 


\section{PRICE LIST FOR 1910}

\section{STRAWBERRY PLANTS}

If by mail, add $10 \mathrm{c}$ per 25 , or $25 \mathrm{c}$ per 100 for postage.

At thousand rates by freight or express only. Fifty of one variety at hundred, or 300 of one variety at thousand rates.

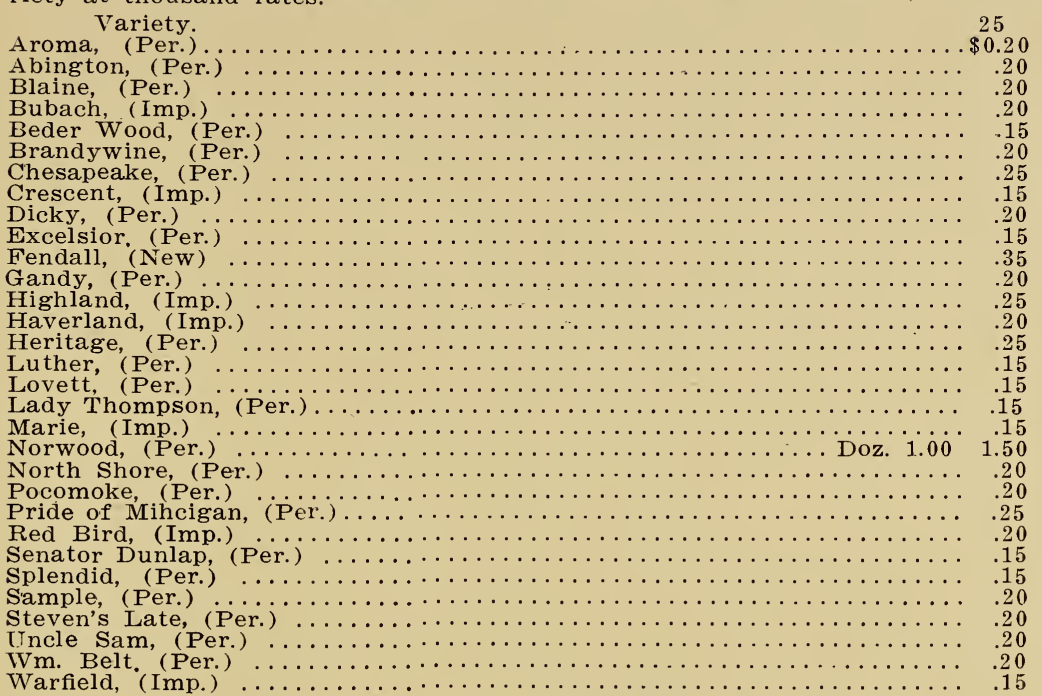

$\begin{array}{rrr}100 & 1,000 & 5,000 \\ \$ 0.60 & \$ 3.75 & \\ .60 & 3.50 & \\ .60 & 4.00 & \$ 17.50 \\ .60 & 4.00 & \\ .50 & 2.25 & 10.00 \\ .60 & 3.50 & 15.00 \\ .75 & 5.00 & \\ .50 & 2.50 & \\ .60 & 4.00 & \\ .50 & 3.00 & 13.00 \\ 1.00 & & \\ .60 & 3.50 & 15.00 \\ .75 & 6.00 & \\ .60 & 3.50 & 15.00 \\ .75 & 5.00 & \\ .50 & 3.00 & 12.50 \\ .50 & 2.50 & 11.00 \\ .50 & 2.50 & 11.00 \\ .50 & 3.00 & \\ 5.00 & & \\ .60 & 3.50 & \\ .60 & 4.00 & 17.50 \\ .75 & 5.00 & \\ .60 & 3.50 & 15.00 \\ .50 & 2.50 & 11.00 \\ .50 & 3.00 & 13.00 \\ .60 & 4.00 & 17.50 \\ .60 & 3.50 & 15.00 \\ .60 & 4.00 & \\ .60 & 3.50 & \\ .50 & 2.50 & 11.00\end{array}$

\section{RASPBERRY PLANTS}

By Express or Freight only; charges not paid. Variety.

Cuthbert, Red

Early King, Red.

Eaton, Red

Miller, Red

Columbian, Purpl

Cardinal, Purple

Haymaker, Purple

Cumberland, Black

Gregg, Black

Conrath, Black

Kansas, Black

Koosier, Black

Munger, Black

\section{BLACKBERRY PLANTS}

Variety.

Early Kin

Wilson's Early

Lucretia, Dewberry

5,000

$\$ 17.50$

10.00

15.00

13.00

15.00

15.00

12.50

11.00

17.50

5.00

11.00

17.50

11.00

\section{CURRANTS}

Variety

Perfection

Wilder

London Market

White Grape

Fay's Prolific

$\begin{array}{rcr}25 & 100 & 1,000 \\ \$ 0.30 & \$ 0.85 & \$ 7.00 \\ .35 & 1.25 & 10.00 \\ 2.50 & 7.50 & \\ .25 & .75 & 6.00 \\ .60 & 2.00 & \\ .60 & 2.25 & \\ .60 & 2.25 & \\ .40 & 1.25 & 10.00 \\ .30 & 1.00 & 8.00 \\ .30 & 1.00 & 8.00 \\ .30 & .85 & 7.00 \\ .50 & 1.50 & 12.00 \\ .40 & 1.25 & 10.00\end{array}$

\section{GOOSEBERRIES}

Variety.
Downing $\ldots . .$.

$\begin{array}{rrr}25 & 100 & 1,000 \\ \$ 0.60 & \$ 2.00 & \$ 17.50 \\ .40 & 1.50 & \\ .30 & .85 & 7.00 \\ .35 & 1.00 & 8.00\end{array}$

Houghton

\section{GRAPE VINES}

Variety. 


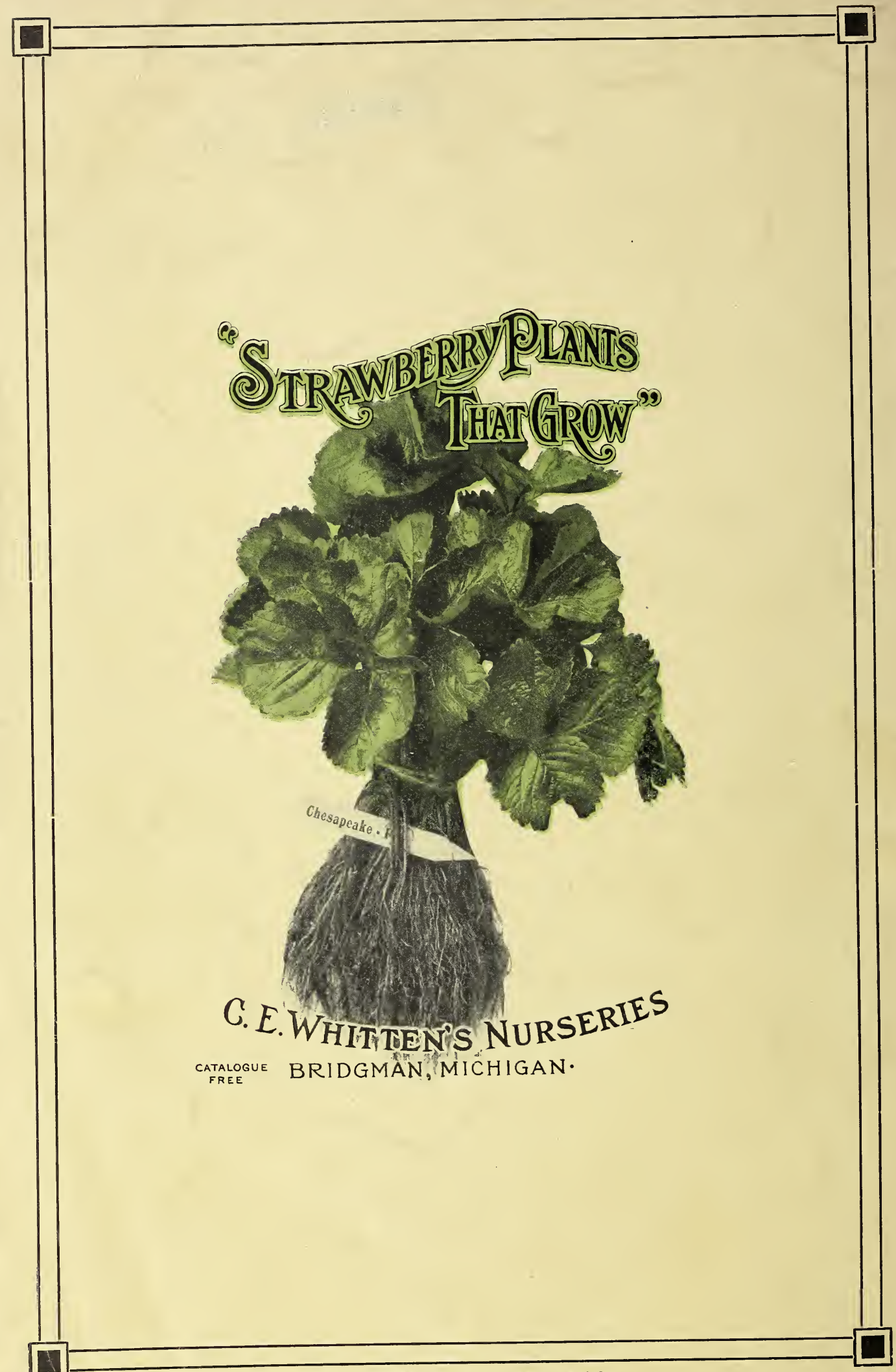

A. B. Morse Co., St. Joseph, Mich. 